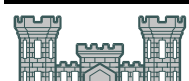

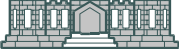

U.S. Army Corps of Engineers

Portland District

\title{
Monitoring and Evaluation of the Prototype Surface Collector at Bonneville First Powerhouse in 2000: Synthesis of Results
}

FINAL REPORT

April 24, 2001

Revised June 22, 2001

Contract DE-AC06-76RLO1830 Related Services

Pacific Northwest National Laboratory

P.O. Box 999

K6-85

Richland, Washington 99352 


\section{DISCLAIMER}

This report was prepared as an account of work sponsored by an agency of the United States Government. Neither the United States Government nor any agency thereof, nor Battelle Memorial Institute, nor any of their employees, makes any warranty, express or implied, or assumes any legal liability or responsibility for the accuracy, completeness, or usefulness of any information, apparatus, product, or process disclosed, or represents that its use would not infringe privately owned rights. Reference herein to any specific commercial product, process, or service by trade name, trademark, manufacturer, or otherwise does not necessarily constitute or imply its endorsement, recommendation, or favoring by the United States Government or any agency thereof, or Battelle Memorial Institute. The views and opinions of authors expressed herein do not necessarily state or reflect those of the United States Government or any agency thereof.

PACIFIC NORTHWEST NATIONAL LABORATORY

operated by

BATTELLE

for the

UNITED STATES DEPARTMENT OF ENERGY

under Contract DE-AC06-76RLO1830 
觜思

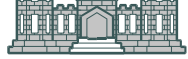

U.S. Army Corps of Engineers

Portland District

\title{
Monitoring and Evaluation of the Prototype Surface Collector at Bonneville First Powerhouse in 2000: Synthesis of Results
}

\author{
FINAL REPORT
}

Prepared by:

G.E. Johnson

(BioAnalysts, Inc.)

T.J. Carlson

(Pacific Northwest National Laboratory)

April 24, 2001

Revised June 22, 2001

Contract DE-AC06-76RLO1830 Related Services

Pacific Northwest National Laboratory

P.O. Box 999

K6-85

Richland, Washington 99352 


\section{Executive Summary}

This project was undertaken as part of the U.S. Army Corps of Engineers, Portland District's (CENWP) surface bypass program at Bonneville First Powerhouse (B1). Pacific Northwest National Laboratory (PNNL) performed the work under contract to CENWP (MIPR No. W66QKZ00200123 and 00125). BioAnalysts, Inc. subcontracted to PNNL (Contract No. 402827-A-B8). Besides synthesis of B1 surface bypass data, this project included tasks in FY2000 on coordination of biological/hydraulic data collection and a pre-study monitoring and evaluation plan. These tasks were accomplished separately from the data synthesis that is the subject of this report.

The data synthesis occurred in two phases. The first phase, reported on December 8, 2000, focused on the PSC performance data, a subset of the total evaluation effort. The second phase, reported herein, includes all components of the 2000 PSC evaluation.

The B1 surface bypass data synthesis will provide information for the 2001 decision on measures for long-term smolt protection at B1. Other projects related to the 2001 decision include the B1 deep slot surface bypass alternatives study by Harza et al. (2000) and research on the efficiency of a prototype extended-length bar screen in Unit 8 by the National Marine Fisheries Service using netting methods and the Waterways Experiment Station using hydroacoustic methods. 


\section{Acknowledgments}

We thank the scientists who performed the research and provided their reports: R. Johnson, G. Ploskey, C. Rakowski, and M. Richmond (Pacific Northwest National Laboratory) and N. Adams, S. Evans, and D. Faber (USGS-Biological Resources Division). We appreciate review comments from D. Dauble (PNNL) and A. Giorgi (BioAnalysts). Finally, we are grateful to the following Portland District staff for their assistance and guidance: L. Ebner, D. Clarke, B. Ebberts, K. Kuhn, R. Lee, and D. Schwartz. 


\section{Contents}

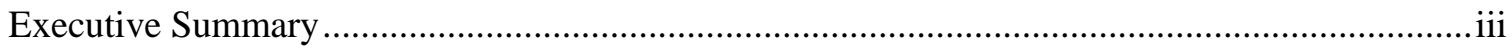

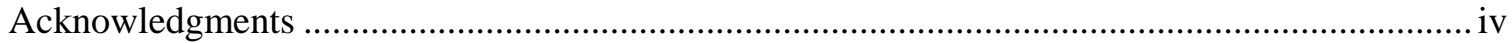

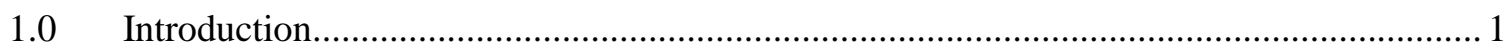

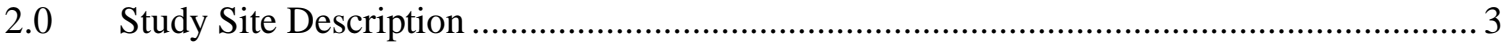

2.1 Structure of the Prototype Surface Collector ..................................................................... 3

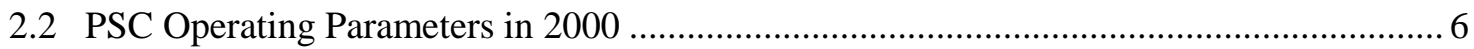

2.3 Species Composition and Run Timing ....................................................................... 7

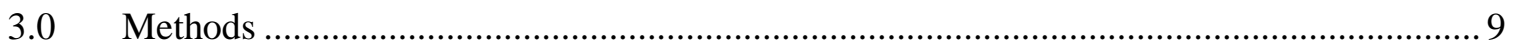

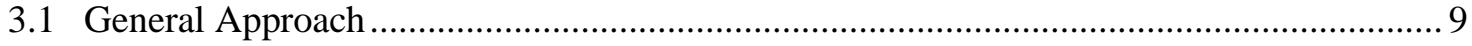

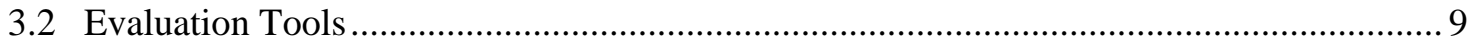

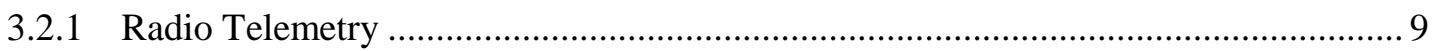

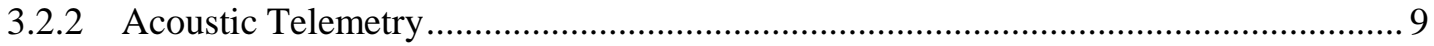

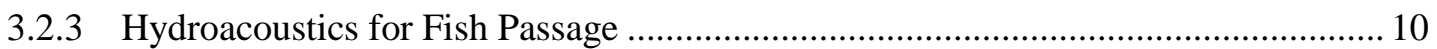

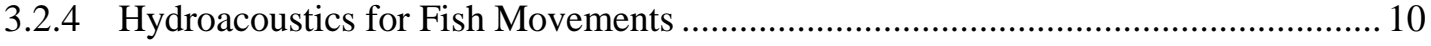

3.2.5 Computational Fluid Dynamics Model ................................................................ 10

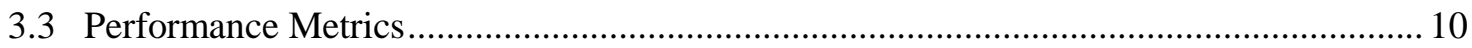

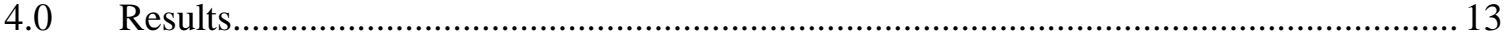

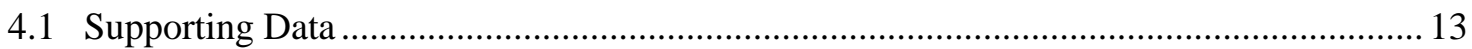

4.1.1 Species Composition and Timing for 2000 Migration............................................. 13

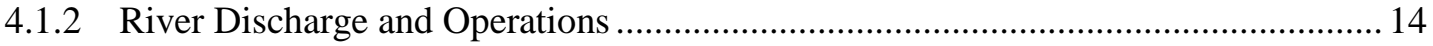

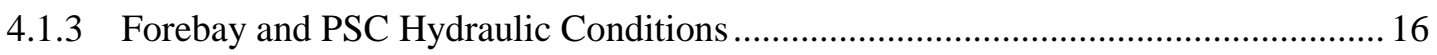

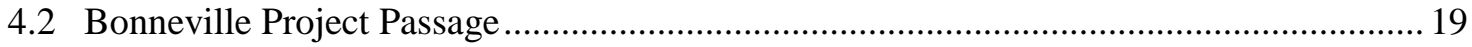

4.3 B1 Forebay Approach and Vertical Distribution ................................................................ 19

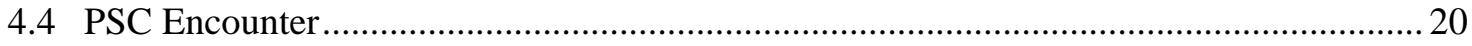

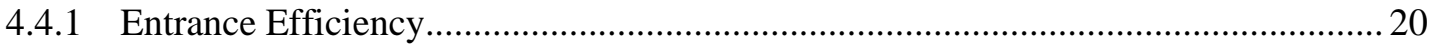

4.4.2 Movement Patterns in the Immediate Vicinity of the PSC ...................................... 21

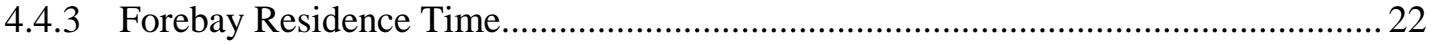

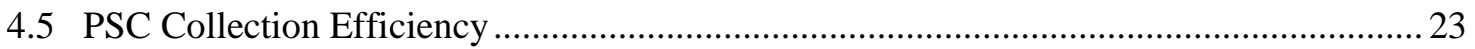




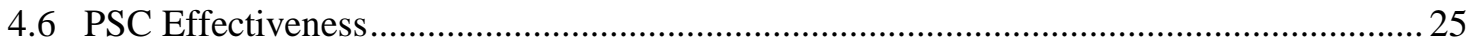

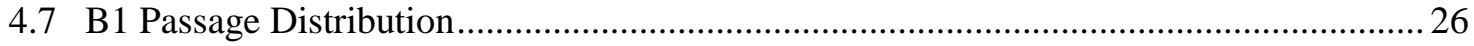

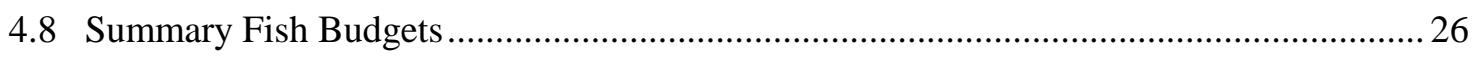

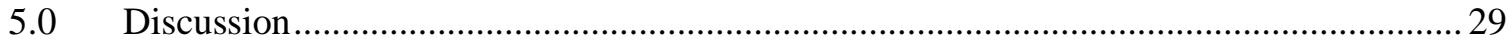

5.1 Comparison of Collection Efficiency Estimates................................................................2 29

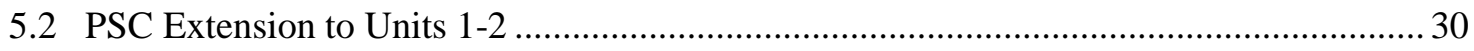

5.3 PSC Entrance Configuration and Turbine Intake Occlusion .......................................... 30

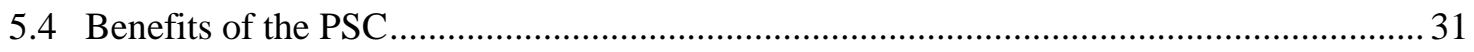

5.5 PSC Performance Compared to Other Regional Surface Bypasses.................................. 31

5.6 Uncertainties and Future Surface Bypass Development at B1 ....................................... 32

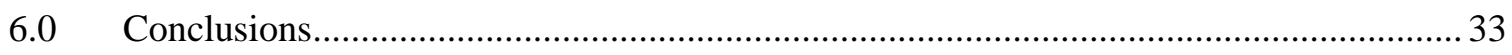

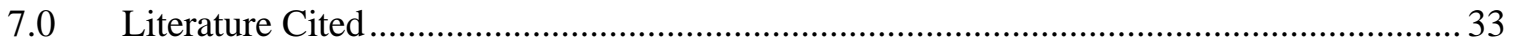

Appendix A. Comments from National Marine Fisheries Service on

Draft Report and Responses...................................................................... A.1 


\section{Figures}

Figure 1. Bonneville Dam on the Columbia River. ............................................................... 4

Figure 2. Plan view of Bonneville First Powerhouse showing location of PSC1-6..................... 4

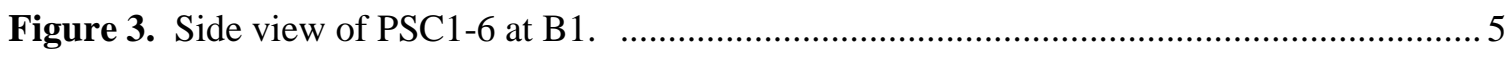

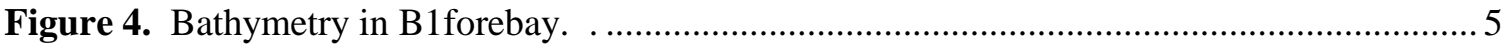

Figure 5. Average daily passage indices by species from the Smolt Monitoring Program at Bonneville Dam from 1994 to 1998, inclusive. ........................................................................ 7

Figure 6. Total smolt passage index for Bonneville Dam in 2000. ........................................ 14

Figure 7. Run timing for juvenile salmon and steelhead at Bonneville Dam in 2000. ............. 14

Figure 8. Total project and spill discharge at Bonneville Dam from April 1 to

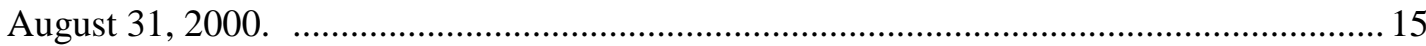

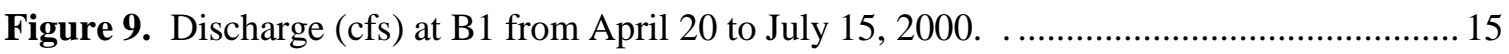

Figure 10. Proportion of total discharge by turbine unit at B1 for spring and summer separately.

Figure 11. Forebay elevation (ft NGVD) at B1 from April 20 to July 15, 2000.

Figure 12. Plan view of B1 forebay showing water velocity (fps) from a CFD model and field measurements with an ADCP (acoustic doppler current profiler).

Figure 13. Side view of B1 PSC showing water velocity (fps) from a CFD model and a 1:25 scale physical model.

Figure 14. Fixed-location hydroacoustic estimates of collection efficiency by unit and overall for spring and summer separately.

Figure 15. Fixed-location hydroacoustic estimates of collection efficiency by 5-day block beginning on April 20 and ending on July 2, 2000.

Figure 16. Fixed-location hydroacoustic estimates of PSC effectiveness by unit and overall for spring and summer separately.

Figure 17. Fixed-location hydroacoustic estimates of total fish passage by unit at B1 for spring and summer separately.

Figure 18. Fish budget using radio telemetry data for steelhead and chinook salmon separately at B1 in 2000. 


\section{Tables}

Table 1. Flows, areas, and velocities for the 5-ft and 20-ft entrance widths at the PSC. 3

Table 2. Evaluation tools employed to obtain data for each PSC performance metric. 11

Table 3. Percentages of juvenile salmon and steelhead migrating through Bonneville Dam from April 3 to August 16, 2000.

Table 4. Passage proportions through B1, the spillway, and B2 as estimated using radio telemetry (RT) for steelhead (ST) and chinook (CH1) salmon and fixed hydroacoustics (HA) for the run-at-large in spring and subyearling chinook (CH0) salmon in summer 2000...... 19

Table 5. Discovery efficiency estimates based on radio (RT) and acoustic (AT) telemetry at B1 in 2000 .

Table 6. Entrance efficiency estimates based on radio and acoustic telemetry at B1 in 2000. .. 21

Table 7. Proportions of acoustic-tagged fish displaying direct passage, searching, and milling movement patterns.

Table 8. Residence time (hours) for radio- and acoustic-tagged fish that passed at B1.

Table 9. Collection efficiency estimates based on hydroacoustics (HA) and radio (RT) and acoustic (AT) telemetry at B1 in 2000.

Table 10. Collection efficiency estimates obtained with hydroacoustics (HA), radio telemetry (RT), and acoustic telemetry (AT) at B1, including the two PSC entrance widths (5-ft and 20-ft).

Table 11. Effectiveness (percent fish divided by percent water) of spill and PSC flow at Bonneville Dam in 2000.

Table 12. Collection efficiencies (CE) for selected surface flow bypasses at Columbia and Snake River dams. 


\subsection{Introduction}

At Bonneville Dam First Powerhouse (B1), the Portland District of the U.S. Army Corps of Engineers (Corps) is evaluating two distinct smolt bypass approaches to provide downstream migrating fish (including several species which are threatened and endangered) with alternative routes to passage through the dams other than through the turbines. The two dam passage alternatives under discussion for Bonneville Powerhouse 1 are surface flow bypass and extendedlength submersible bar screens. The year 2001 has been scheduled for a decision on which suite of smolt passage measures to emphasize for long-term smolt protection at B1. The Corps is planning to prepare a special report, called the Decision Document, to analyze the relative merits of surface bypass and other passage devices at B1.

The goal of the surface flow bypass ${ }^{1}$ program is to "develop and evaluate surface bypass and collection prototype concepts that will lead, if justified by prototype test results, to permanent systems for improving survival of juvenile salmon..." (USACE 1995). In 1998, a prototype surface collector (PSC) was installed at Units 3-6 and was extensively studied (see Johnson and Giorgi 1999 for a review). In 1999, limited research occurred to prepare for tests in 2000. In 2000, the PSC was extended from Units 3-6 to also cover Units 1-2, because a noticeable number of smolts were observed in 1998 and 1999 to move obliquely from north to south across the forebay of the PSC. A thorough evaluation of the PSC was conducted in 2000 as part of the Anadromous Fish Evaluation Program (AFEP). The general objectives for surface bypass research at B1 in 2000 were to 1) confirm proof-of-concept for surface bypass at B1 that was established in 1998, 2) estimate PSC performance metrics; and 3) study behavioral processes and mechanisms that affect performance to aid future surface bypass designs.

The 2000 PSC evaluation emphasized PSC performance, i.e., efficiency, as well as forebay fish movements. It included the following biological research (AFEP study codes are given in parentheses):

- fixed radio telemetry to determine species-specific PSC performance and movement patterns for yearling chinook salmon and steelhead (SBE-P-95-6)

- acoustic telemetry to study three-dimensional movement patterns and PSC performance for yearling chinook salmon and steelhead (SBE-P-00-14)

- fixed hydroacoustics to estimate fish passage rates and determine PSC performance for the run-at-large during spring and summer (SBE-P-98-8a)

- multi- and split-beam hydroacoustics to assess fish movements near the PSC (SBE-P-98-8b)

\footnotetext{
${ }^{1}$ A surface flow bypass provides a non-turbine passage route extending from the water surface to some depth that takes advantage of the natural, surface-oriented distribution of smolts. See Johnson, Giorgi, and Erho (1997) and Dauble, Anglea, and Johnson (1999) for reviews of surface bypass development on the Columbia and Snake rivers.
} 
- computational fluid dynamics modeling to document forebay hydraulic conditions (no AFEP code)

- numerical modeling to integrate hydraulic data from a computational fluid dynamics model with three-dimensional fish movement data (SBE-P-00-13).

The purpose of this report, prepared by Pacific Northwest National Laboratory (PNNL), is to consolidate results from surface bypass studies at B1 in 2000. We are especially interested in results for yearling spring chinook salmon (Oncorhynchus tshawyscha), steelhead ( $O$. mykiss), and subyearling chinook salmon (O. tshawyscha), in addition to the run-at-large. The focus of this report is on surface bypass research at B1 that is relevant to the Decision Document. The sources for the data presented in this report are, for the most part, draft reports. Therefore, the data should be used cautiously as they are subject to change.

This report does not address extended-length screens, passage at the spillway, or research at the Bonneville Second Powerhouse. Specific objectives were to

- review results from the 2000 PSC studies

- relate 2000 results to previous findings (1998 and 1999)

- make conclusions about PSC performance (its potential to collect fish) on a species-specific basis and for the run-at-large.

After the introduction in Section 1, this report contains a description of the B1 PSC study site in Section 2. Methods used in the various studies we are synthesizing are presented briefly in Section 3. Data are summarized in Section 4 and discussed in Section 5. Conclusions are rendered in Section 6 and literature is cited in Section 7. The report closes with an appendix containing draft comments from the National Marine Fisheries Service on the Phase 1 report dated December 8, 2000, and our responses to the comments. 


\subsection{Study Site Description}

This section contains a description of the study site including data on the PSC structure, PSC set-up parameters, and species composition and run timing from 1994 through 1998.

\subsection{Structure of the Prototype Surface Collector}

A detailed description of the PSC test structure may be found in Harza and ENSR (1996). The PSC was retrofitted to the upstream face of B1 at Units 1-6 (Table 1 and Figures 1, 2 and 3). Vertical slots in the PSC in front of middle (B) intakes at each unit were configured to have 5-ft or 20-ft wide openings. These widths were chosen to maximize differences in flows and velocities between the configurations to increase the likelihood of detecting differences in smolt response to PSC slot-widths. PSC entrances were 40-46 ft deep depending on forebay level (PSC floor was at El. $30.5 \mathrm{ft}$ ). The mean velocity at the entrance ranged from 3.8 to $8.3 \mathrm{fps}$, depending on slot width (Table 1). Flow through the entrances was 1,700 cfs for 5-ft slots and 3,300 cfs for 20 -ft slots. The PSC was located in the thalweg of the Columbia River at B1 (Figure 4).

Table 1. Flows, areas, and velocities for the 5-ft and 20-ft entrance widths at the PSC.

Data are for forebay El. $75.0 \mathrm{ft}$, floor El. $30.5 \mathrm{ft}$, and turbine unit discharge $\sim 10,000 \mathrm{cfs}$.

\begin{tabular}{lcc}
\hline & 5-ft & 20-ft \\
\hline PSC flow (cfs) & 1,700 & 3,300 \\
Area (ft $\left.{ }^{2}\right)$ & 223 & 890 \\
Velocity (fps) & $7.1-8.3$ & $3.8-4.6$ \\
\hline
\end{tabular}

Fish passing via the PSC migrated through the structure into the turbine intake or sluice gate behind the PSC (Figure 3). The PSC was not designed to actually bypass fish around turbines during the test periods. The intent was to use the PSC to examine entrance hydraulics and to examine the efficacy of surface bypass at B1 before building a large-scale prototype or full production surface bypass facilities. 


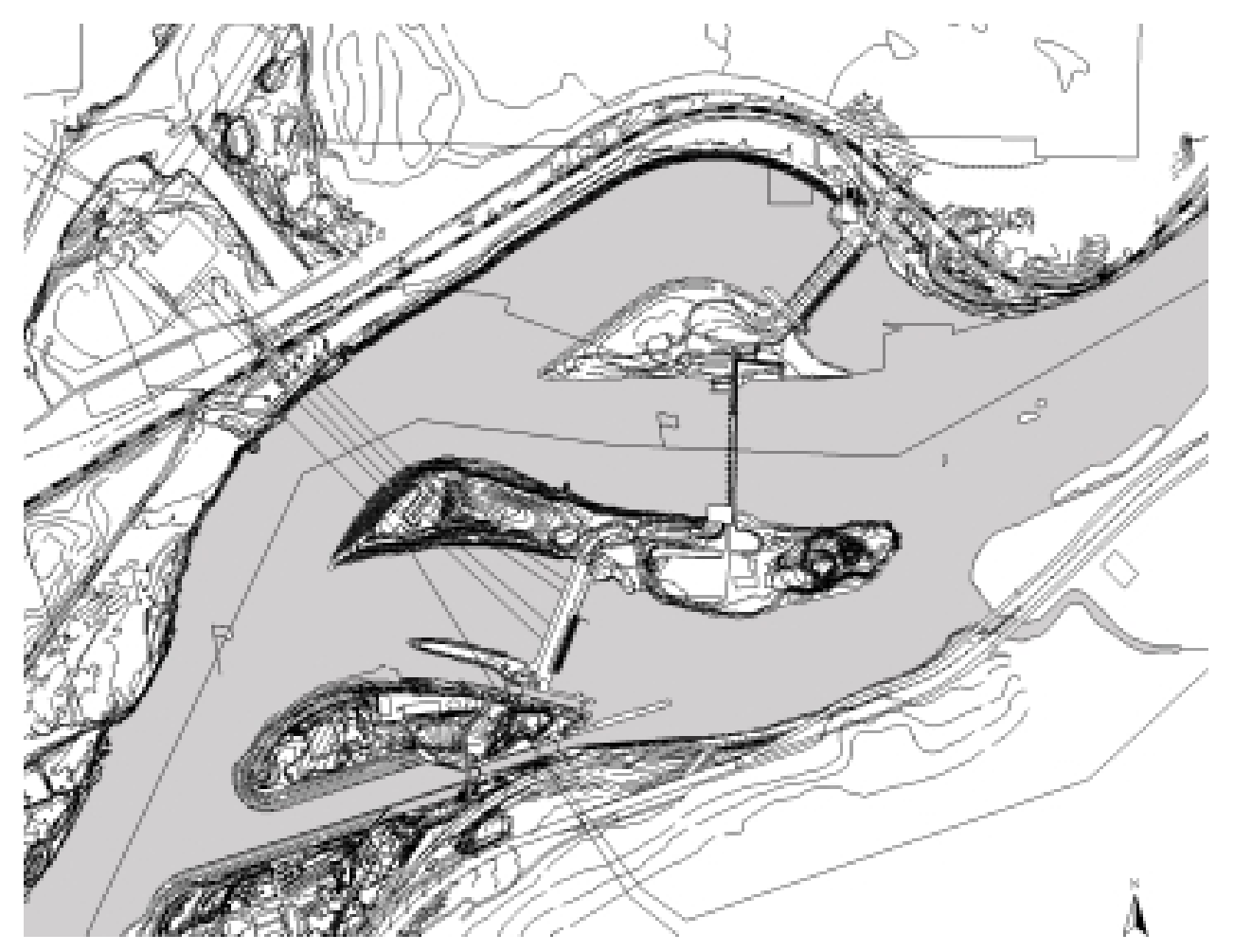

Figure 1. Bonneville Dam on the Columbia River

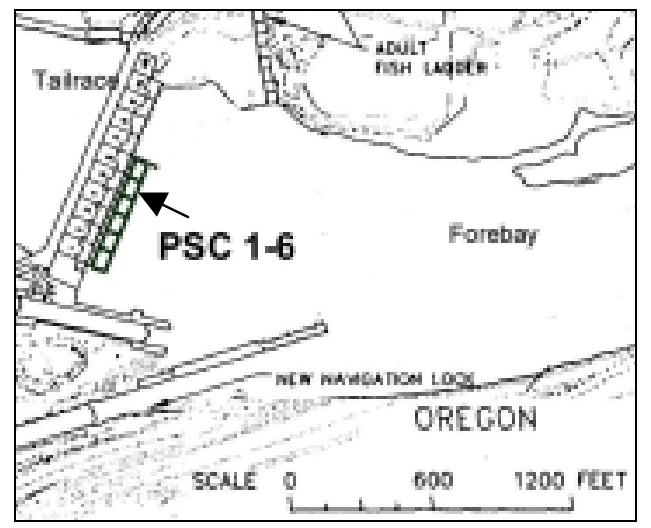

Figure 2. Plan view of Bonneville First Powerhouse showing location of PSC 1-6. 


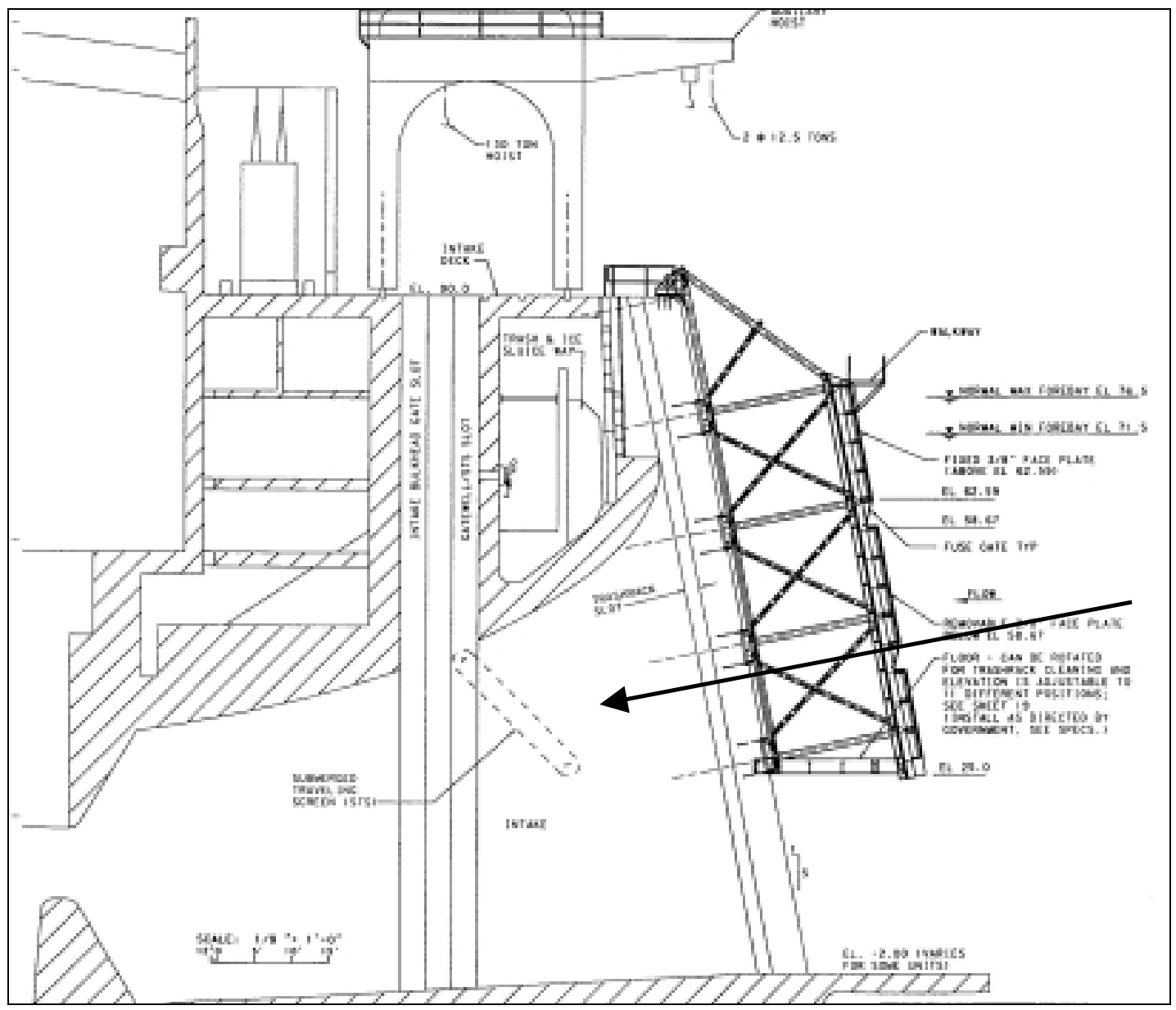

Figure 3. Side view of PSC1-6 at B1. Arrow depicts flow into and through the PSC.

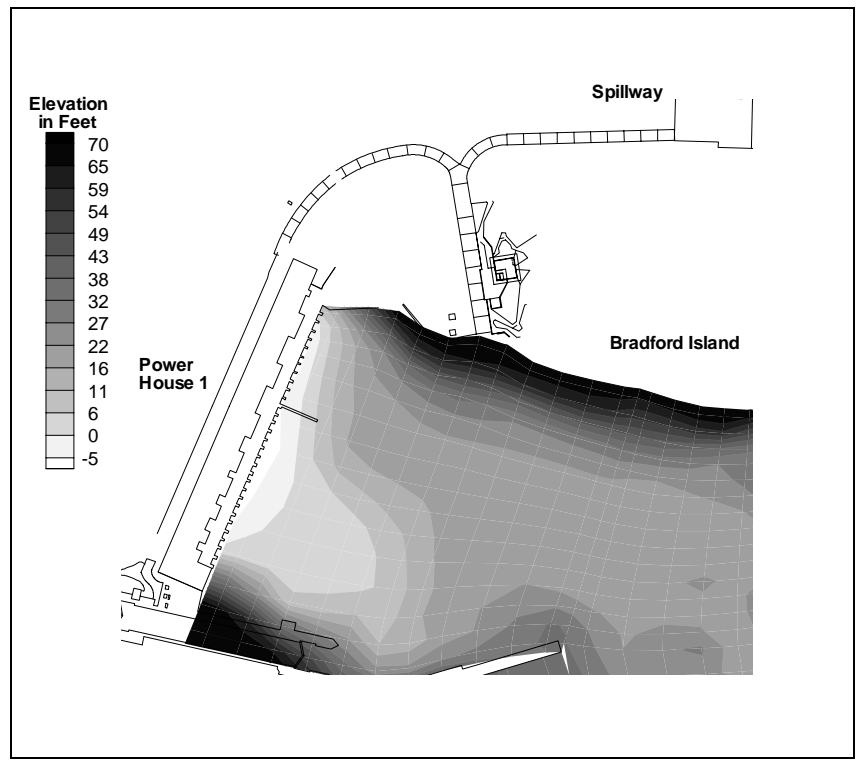

Figure 4. Topography of B1forebay (relative to mean sea level). Provided by C. Rakowski (Pers. Comm. Dec. 5, 2000). 


\subsection{PSC Operating Parameters in $\mathbf{2 0 0 0}$}

Operation of the PSC in 2000 was influenced by the following parameters: PSC trashracks, entrance widths, entrance locations, turbine operations, sluiceway operations, forebay elevation, intake screens, and experimental design.

PSC Trashracks - The PSC trashracks were in place during the 1998 and 1999 tests. However, project maintenance does not require them because there are trashracks at the turbine intakes. Also, it was possible the PSC trashracks could cause some smolts to avoid the PSC entrances. Thus, the PSC trashracks were removed for the 2000 test.

PSC Entrance Widths - During the 1998 and 1999 tests, PSC performance and fish behavior were compared for 5-ft vs. 20-ft wide vertical entrances at PSC 3 and PSC 5. In 1998, the 20-ft entrance was more efficient ${ }^{2}$ than the 5-ft entrance in spring (Hensleigh et al. 1998 and Ploskey et al. 1998a). In summer 1998, Ploskey et al. (1998a) found that the collection efficiencies for 5-ft and 20-ft entrances were similar, while Hensleigh et al. (1998) reported that the 20-ft entrance had much higher efficiency than the 5-ft entrance. Results from the 1999 hydroacoustic study were similar to those in 1998 (G. Ploskey, pers. comm.). Given the 19981999 results, it did not seem necessary to continue to compare 5 - $\mathrm{ft}$ and $20-\mathrm{ft}$ entrance widths in 2000. Thus, PSC entrance width was a constant $20 \mathrm{ft}$ in 2000.

PSC Entrance Locations - The PSC had the capability for six entrances, one in front of the B-intake of each unit at Units 1-6. To maximize PSC passage, all six entrances were opened.

Turbine Operations - For purposes of the PSC evaluation, Turbine Units 1-6 were priority units at B1 in 2000 to reduce hydraulic variability at the PSC. Units 1-6 were all operational for PSC tests in spring and summer 2000.

Sluiceway Operations - Based on our observations, open sluice gates at the B-slots behind the PSC entrances appeared to improve hydraulics in the PSC, at least at the surface. (Sluiceway flow probably had little effect on hydraulic conditions at depths below about $2 \mathrm{~m}$ within the PSC.) For example, without an open sluice gate, surface flow was sometimes moving upstream and out of the PSC in the B slot (G. Ploskey, pers. comm.). Upstream flow inside the PSC was considered undesirable because smolt passage through the PSC may be reduced. Thus, B-slot sluice gates behind each PSC entrance were opened with the weir crest at El. $72 \mathrm{ft}$ for the 2000 study.

Forebay Elevation - Forebay elevation affected PSC inflows because the PSC was fixed in place. To minimize this effect on the PSC test in 2000, the monitoring and evaluation plan called for forebay elevation to be constrained at $\pm 1 \mathrm{ft}$ around El. $74.5 \mathrm{ft}$. (See Section 4.1.2 for actual forebay elevations during the evaluation.)

Intake Screens - Intake screens were deployed at Units 1-6 during testing.

${ }^{2}$ Collection efficiency defined on p. 10 . 


\subsection{Species Composition and Run Timing}

Juvenile chinook salmon, coho salmon, sockeye salmon, and steelhead trout migrate downstream through Bonneville Dam. Some of these fish have stream-type life histories, i.e., they migrate downstream as yearling fish in the spring. Others have ocean-type life histories, and migrate downstream as subyearlings in the summer. (Note that subyearling chinook salmon released from nearby hatcheries also migrate through Bonneville Dam in spring.)

The migration of yearling salmonids occurs from early April until late June (Figure 5). Peaks in run timing vary, but are usually in late April or May (Figure 5). Migration magnitude generally declines in late May and June (Figure 5).

Subyearling chinook salmon have the highest daily passage indices of all outmigrants at Bonneville Dam, as reported in the Smolt Monitoring Program during 1994-1998 (Figure 5). The migration of subyearling fish begins with the major release from the Spring Creek hatchery in April (Figure 5). Another peak in subyearling passage can occur in late May. Subyearling fish migrate through Bonneville Dam until late July or early August (Figure 5). (Species composition and run timing for 2000 are presented in Section 4.1.)
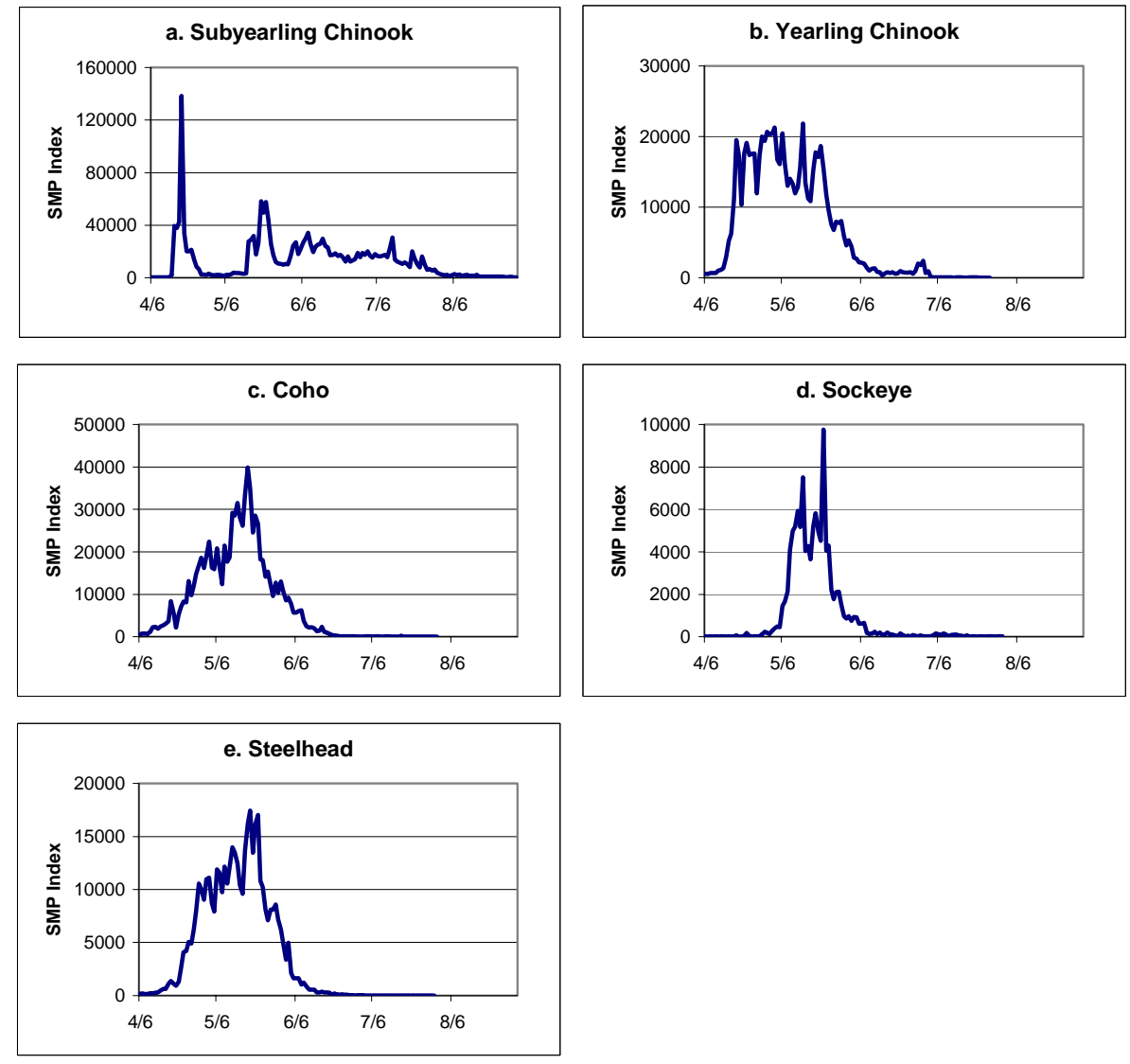

Figure 5. Average daily passage indices by species from the Smolt Monitoring Program at Bonneville Dam from 1994 to 1998, inclusive. Note the index scales differ among graphs. Data are from a web page (www.cbr.washington.edu/DART/). 


\subsection{Methods}

Study methods are presented briefly for the performance metrics and each of the main performance evaluation tools: radio telemetry, acoustic telemetry, hydroacoustics for fish passage, hydroacoustics for fish movements, a computational fluid dynamics model, and a numerical fish movement model. ${ }^{3}$ Detailed methods and objectives may be found in the respective reports.

\subsection{General Approach}

The B1 PSC evaluation in 2000 emphasized performance (i.e., efficiency) and fish movements (i.e., processes); the study did not have experimental treatments. The PSC and associated turbines and sluice gates were operated as constantly as possible. Relatively steady dam operations reduced environmental variability, thereby improving the conditions under which researchers investigated the biological processes affecting PSC performance.

\subsection{Evaluation Tools}

\subsubsection{Radio Telemetry}

The Biological Resources Division of the U.S. Geological Survey (BRD) used radio telemetry to study the movement, distribution, and passage behavior of juvenile salmonids at Bonneville Dam in 2000 (Evans et al. 2001). They radio-tagged and released 1,193 steelhead and 2,075 yearling chinook salmon in the Columbia River at the Hood River Bridge and well upstream. Mean fork length was $222 \mathrm{~mm}$ for steelhead and $155 \mathrm{~mm}$ for chinook salmon. Aerial and underwater radio telemetry antennas were deployed to determine specific passage routes at the dam for each tagged fish. The primary purpose of the radio telemetry study was to provide species-specific data on PSC performance including discovery efficiency, entrance efficiency, collection efficiency, effectiveness, and residence time.

\subsubsection{Acoustic Telemetry}

PNNL, BRD, and the Corp's Waterways Experiment Station (WES) used acoustic telemetry to study movements and passage of juvenile spring chinook salmon and steelhead at B1 in 2000 (Faber et al. 2001). They acoustic-tagged and released 331 steelhead and 163 yearling chinook salmon at the Hood River Bridge. The acoustic detection zone extended horizontally the length of B1, vertically from the surface to the bottom, and longitudinally from B1 upstream about $100 \mathrm{~m}$. The main purpose of the acoustic telemetry study was to furnish three-dimensional data on fish movements during forebay approach and encounter with the PSC. Acoustic telemetry also provided data on species-specific performance of the PSC.

\footnotetext{
${ }^{3}$ Development of the numerical fish model was still underway when this report was written, because it could only start in earnest when results from the biological and hydraulic research were available.
} 


\subsubsection{Hydroacoustics for Fish Passage}

The WES used fixed-location hydroacoustic methods to evaluate fish passage at the PSC (Ploskey et al. 2000a) and overall passage at Bonneville Dam (Ploskey et al. 2000b) in 2000. Their PSC study was divided into two sampling periods, spring (April 20 to June 1) and summer (June 5 to July 2). Although hydroacoustics cannot determine the species of a fish detected, hydroacoustic results can be ascribed to one particular species when that species comprises most of the targets; such was the case during the summer period at B1 with subyearling chinook salmon. Single-beam transducers were deployed inside all 18 turbine intakes (3 intakes per turbine unit) associated with the PSC at Units 1-6. These transducers were located and aimed to sample PSC fish passage as well as fish passage under the PSC. Fish that entered the PSC but passed into the sluiceway were not sampled by hydroacoustics. The primary purpose of the hydroacoustic study for fish passage was to supply data on PSC performance for the run-at-large including collection efficiency, effectiveness, and horizontal distribution.

\subsubsection{Hydroacoustics for Fish Movements}

PNNL used multi- and split-beam hydroacoustic techniques to study fish movements for the run-at-large at B1 in 2000 (Johnson et al. 2001). Dual-head multi-beam sonar was deployed from a barge $18 \mathrm{~m}$ upstream of the PSC and aimed back at the Unit 3 entrance (PSC 3B). Three stationary transducers and one traversing split-beam transducer were located immediately upstream of PSC 3B. The multi- and split-beam transducers sampled fine-scale $(<0.1 \mathrm{~m})$ fish movements in the nearfield $(<3 \mathrm{~m})$ and intermediate fields $(<18 \mathrm{~m})$ of the PSC at Unit 3. The primary purpose of the hydroacoustic study for fish movements (April 15 to July 15, 2001) was to characterize smolt movements with respect to time of day, vertical position, and water velocity.

\subsubsection{Computational Fluid Dynamics Model}

PNNL developed a computational fluid dynamics model (CFD) for the forebay at B1 (Rakowski et al. 2000). This model, developed with StarCD software, provided detailed hydraulic data for the B1 forebay, including the PSC entrances. The primary purpose of the CFD model was to characterize the hydraulic environment at the PSC and provide hydraulic data to integrate with biological data, e.g., hydroacoustic and telemetry results.

\subsection{Performance Metrics}

The following performance metrics were estimated for the PSC evaluation in 2000. The evaluation tool(s) used to provide data for each metric are listed in Table 2.

- PSC discovery efficiency (DE) for the B1 forebay.

$\mathrm{DE}=$ Number of fish available (within $6 \mathrm{~m}$ ) to the PSC divided by the number that entered the B1 forebay

- PSC entrance efficiency (EE) for fish within 6 m relative to Units 1-6 (EE $\left.\mathrm{EE}_{1-6}\right)$.

$\mathrm{EE}=\mathrm{PSC}$ passage divided by the total number of fish available within $6 \mathrm{~m}$ of the PSC entrances 
- PSC collection efficiency relative to Units 1-6 $\left(\mathrm{CE}_{1-6}\right)$ and individual areas (e.g., Units 1 and $\left.2, \mathrm{CE}_{1-2}\right)$.

$\mathrm{CE}=\mathrm{PSC}$ passage divided by PSC passage plus passage under the PSC

- PSC effectiveness relative to Units 1-6 $\left(\mathrm{EF}_{1-6}\right)$ and individual areas (e.g., Unit 1, $\left.\mathrm{EF}_{1}\right)$.

$\mathrm{EF}=$ Collection efficiency divided by water passage efficiency which is the proportion of flow into a particular PSC entrance(s) out of the total turbine discharge at that same unit (s).

- Residence time (RES) in the forebay for each route of passage (into PSC, under PSC, and into Units 7-10) by species.

RES $=$ time between first and last detections

- Vertical distribution in the immediate vicinity of the PSC.

- Horizontal distribution of passage at B1.

Table 2. Evaluation tools employed to obtain data for each PSC performance metric. Hydroacoustics $=$ HA; radio telemetry $=$ RT; and acoustic telemetry $=$ AT .

\begin{tabular}{lccc}
\hline Metric & HA & RT & AT \\
\hline Discovery Efficiency & --- & X & X \\
Entrance Efficiency & --- & X & X \\
Collection Efficiency & X & X & X \\
Effectiveness & X & X & X \\
Residence Time & --- & X & X \\
Vertical Distribution & $\mathrm{X}$ & $\mathrm{X}$ & --- \\
Horizontal Distribution & $\mathrm{X}$ & $\mathrm{X}$ & --- \\
\hline
\end{tabular}




\subsection{Results}

Data for the PSC evaluation in 2000 are organized into the following sections: Supporting Data, Bonneville Project Passage, B1 Forebay Approach, PSC Encounter, PSC Collection Efficiency, Effectiveness, B1 Passage Distribution, and Summary Fish Budgets.

\subsection{Supporting Data}

This section includes the following supporting data for the 2000 PSC study: species composition and run timing, river discharge and project operations, and forebay and PSC hydraulic conditions.

\subsubsection{Species Composition and Run Timing}

The most common juvenile salmonid migrating through Bonneville Dam in 2000 was yearling chinook salmon, comprising about $35 \%$ of the total (Table 3). Subyearling chinook and coho salmon were also common. Steelhead comprised about $9 \%$ of the emigration, and juvenile sockeye salmon $<1 \%$.

Table 3. Percentages of juvenile salmon and steelhead migrating through Bonneville Dam from April 3 to August 16, 2000. $\mathrm{CH} 0=$ subyearling chinook salmon, $\mathrm{CH} 1=$ yearling chinook salmon, Sock = sockeye salmon, and ST = steelhead. Data derived from smolt passage indices produced by the Smolt Monitoring Program (www.cbr.washington.edu/DART/).

\begin{tabular}{ccccc}
\hline CH0 & CH1 & Coho & Sock & ST \\
\hline $28.3 \%$ & $34.6 \%$ & $27.1 \%$ & $0.9 \%$ & $9.0 \%$ \\
\hline
\end{tabular}

The 2000 migration of juvenile fish past Bonneville Dam started in earnest around April 15 (Figure 6) and peaked on April 22 (Figure 6). Hatchery subyearling chinook salmon dominated this early peak (Figure 7). The second highest run timing peak occurred on May 21, and included high numbers of subyearling chinook salmon, in addition to yearling chinook and coho salmon and steelhead (Figures 6 and 7). The migration of juvenile salmonids was essentially over by mid-July (Figure 6).

The hydroacoustic study period in spring (April 20-June 2) included a mixture of several species (Figure 7). In contrast, subyearling chinook salmon dominated the smolt population during the summer study period (June 6-July 2) (Figure 7). 


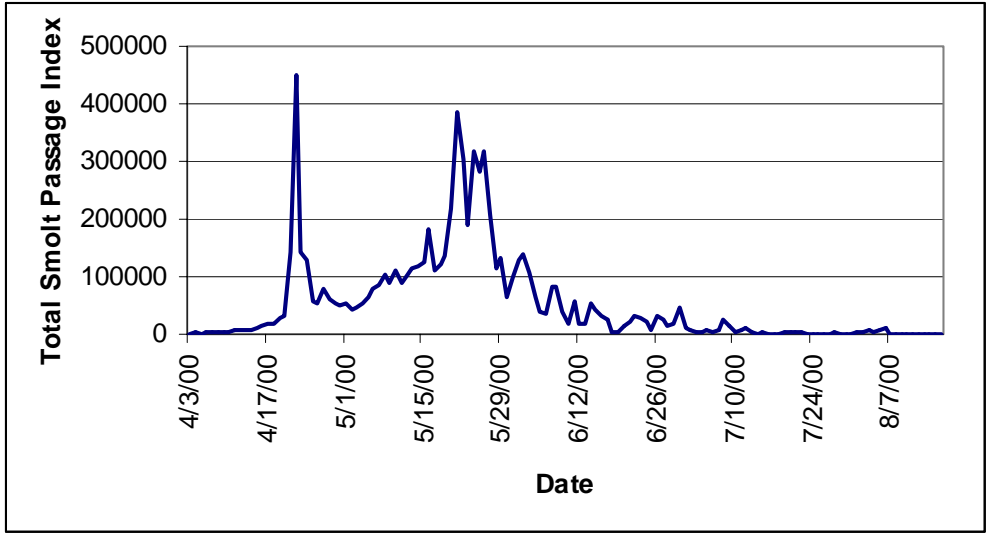

Figure 6. Total smolt passage index for Bonneville Dam in 2000. Smolt index data are from the Smolt Monitoring Program (www.cbr.washington.edu/DART/).

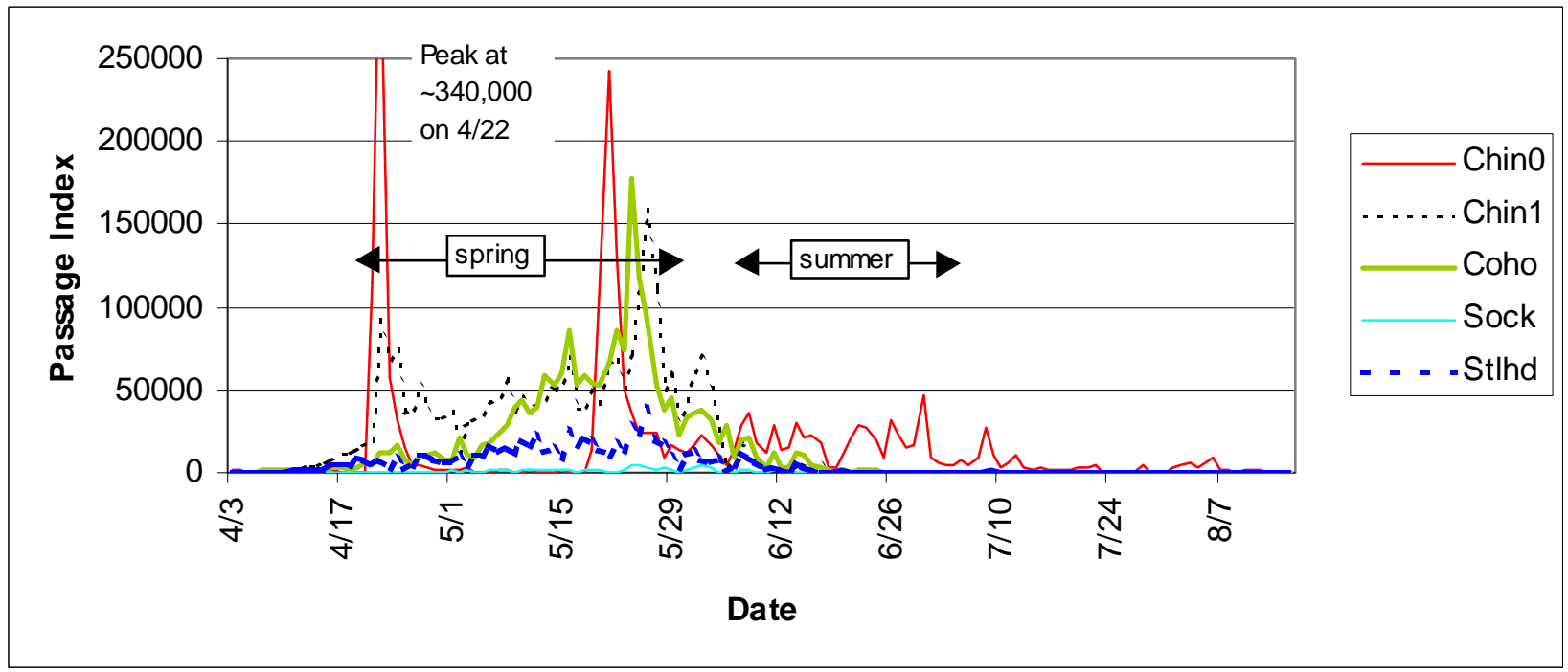

Figure 7. Run timing for juvenile salmon and steelhead at Bonneville Dam in 2000. Spring and summer sampling periods for the hydroacoustic study are shown. Smolt index data are from the Smolt Monitoring Program (www.cbr.washington.edu/DART/).

\subsubsection{River Discharge and Operations}

During the 2000 PSC evaluation (April 20 to July 2), total river discharge at Bonneville Dam ranged from $387 \mathrm{kcfs}$ on April 23 to $156 \mathrm{kcfs}$ on July 2 (Figure 8). Total discharge generally declined during the study. Spill discharge was about 80-110 kcfs throughout the study (Figure 8). In spring (April 20 to June 1), discharge distribution was 32\% for B1, 33\% for the spillway, and $35 \%$ for B2. In summer (June 5 to July 2), the discharge distribution was $41 \%$ for B1, $48 \%$ for the spillway, and $11 \%$ for B2. 


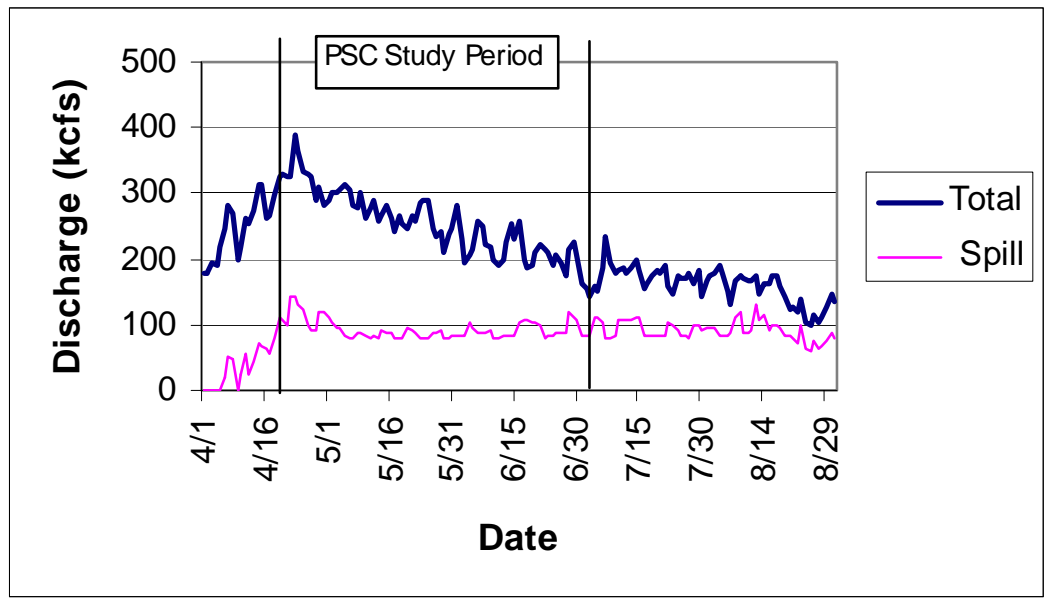

Figure 8. Total project and spill discharge at Bonneville Dam from April 1 to August 31, 2000. Data were obtained from DART (www.cbr.washington.edu/DART/).

Discharge at B1 was somewhat variable between 80 and $100 \mathrm{kcfs}$ from April 20 to July 15 (hour 1 to 1,368 in Figure 9). The range during this period was 20-126 kcfs with a mean of 85 kcfs. Discharge at Units 1-6, where the PSC was located, was fairly constant at 50-60 kcfs (Figure 9), ranging from 9 to $67 \mathrm{kcfs}$ with a mean of $53 \mathrm{kcfs}$. Recall, Units 1-6 were the priority units at B1 during the PSC evaluation. Discharge dropped dramatically starting on July 10 after the study was essentially completed. Discharge among units at B1 was fairly uniform except for Unit 10 in spring (Figure 10). Unit 9 passed the most water in spring, but Unit 10 passed the most water in summer.

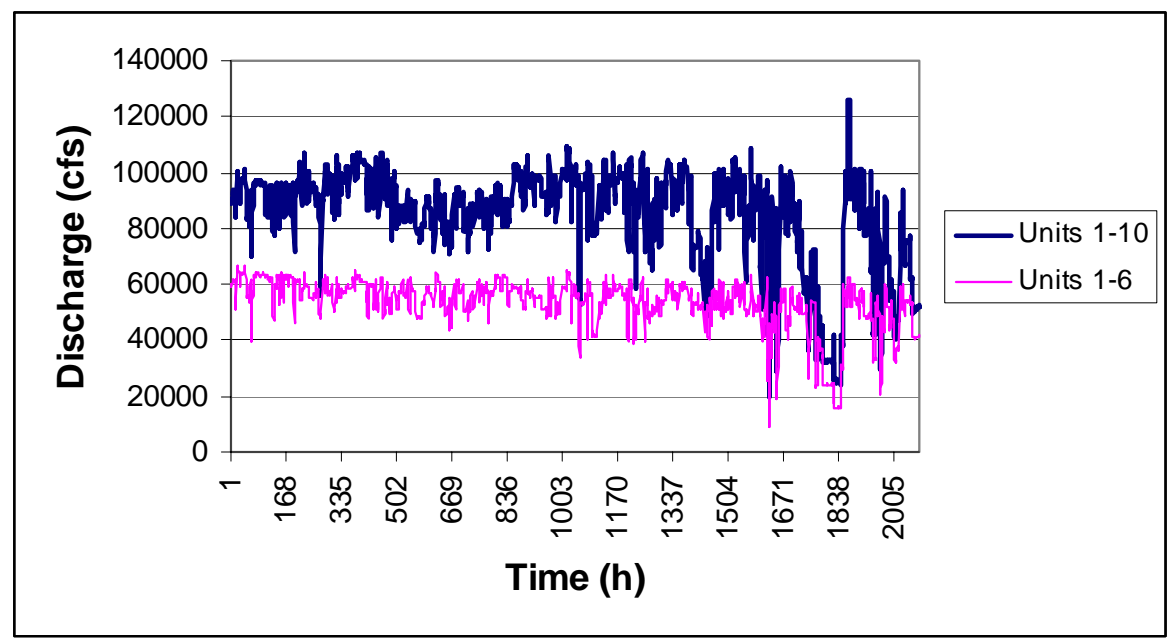

Figure 9. Discharge (cfs) at B1 from April 20 to July 15, 2000. Time marks on the $\mathrm{x}$-axis are at 1-week intervals. Data were obtained from G. Ploskey (Pers. Comm. December 5, 2000). 


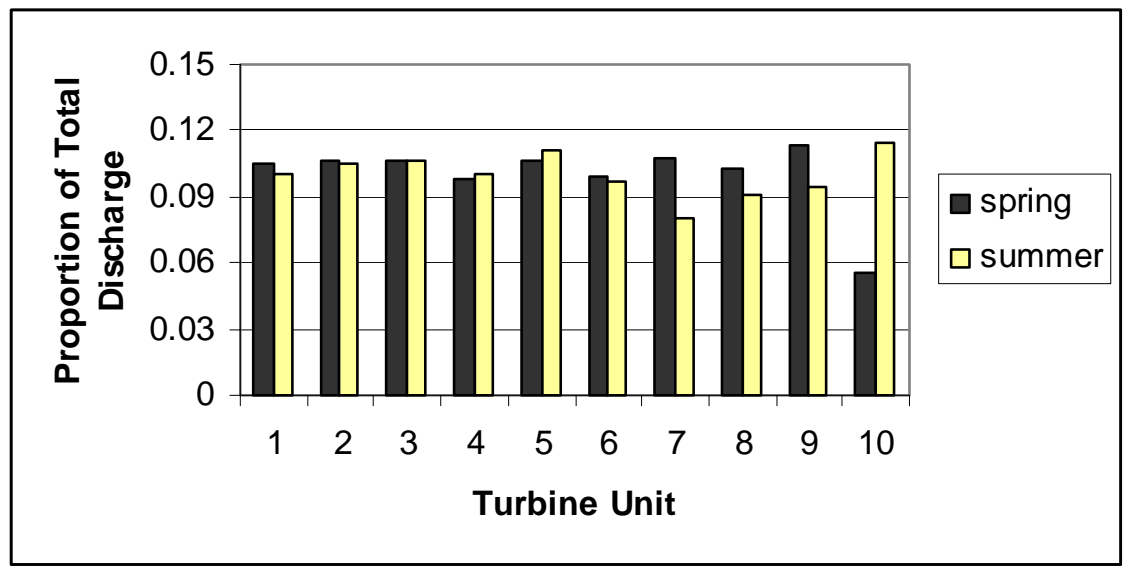

Figure 10. Proportion of total discharge by turbine unit at B1 for spring and summer separately. Data were obtained from G. Ploskey (Pers. Comm. December 5, 2000).

From April 20 to July 15, 2000, at Bonneville Dam, forebay elevation ranged from 71.0 to $75.7 \mathrm{ft}$ (Figure 11). The mean elevation was $73.6 \mathrm{ft}$. The desired range was $73.5-75.5 \mathrm{ft}( \pm 1 \mathrm{ft}$ around El. $74.5 \mathrm{ft}$ ). Thus, forebay elevation was more variable and lower overall than planned. Any effect on the PSC evaluation was probably inconsequential, although researchers are not specifically examining this condition.

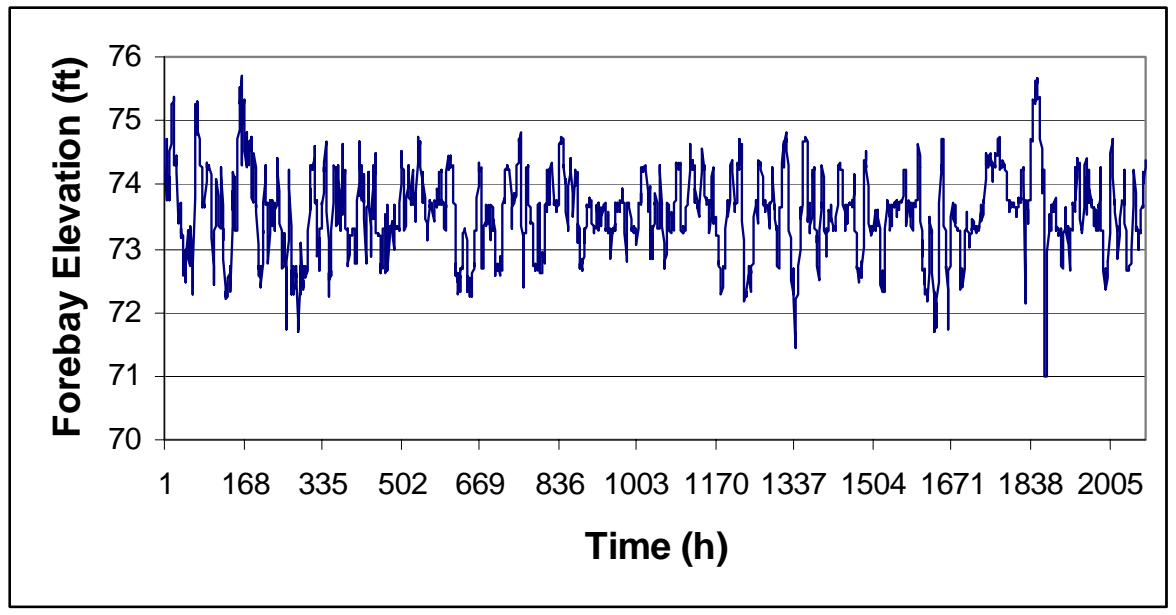

Figure 11. Forebay elevation (ft NGVD) at B1 from April 20 to July 15, 2000. Time marks on the $\mathrm{x}$-axis are at 1-week intervals. Data were obtained from G. Ploskey (Pers. Comm. December $5,2000)$.

\subsubsection{Forebay and PSC Hydraulic Conditions}

Water velocity in the B1 forebay is generally higher in the north half than the south half (Figure 12). Flow relatively close to Units 1-6 (within $100 \mathrm{ft}$ ) has a southerly component. At the PSC velocities are about 4-7 fps and have a downward component (Figure 13). 


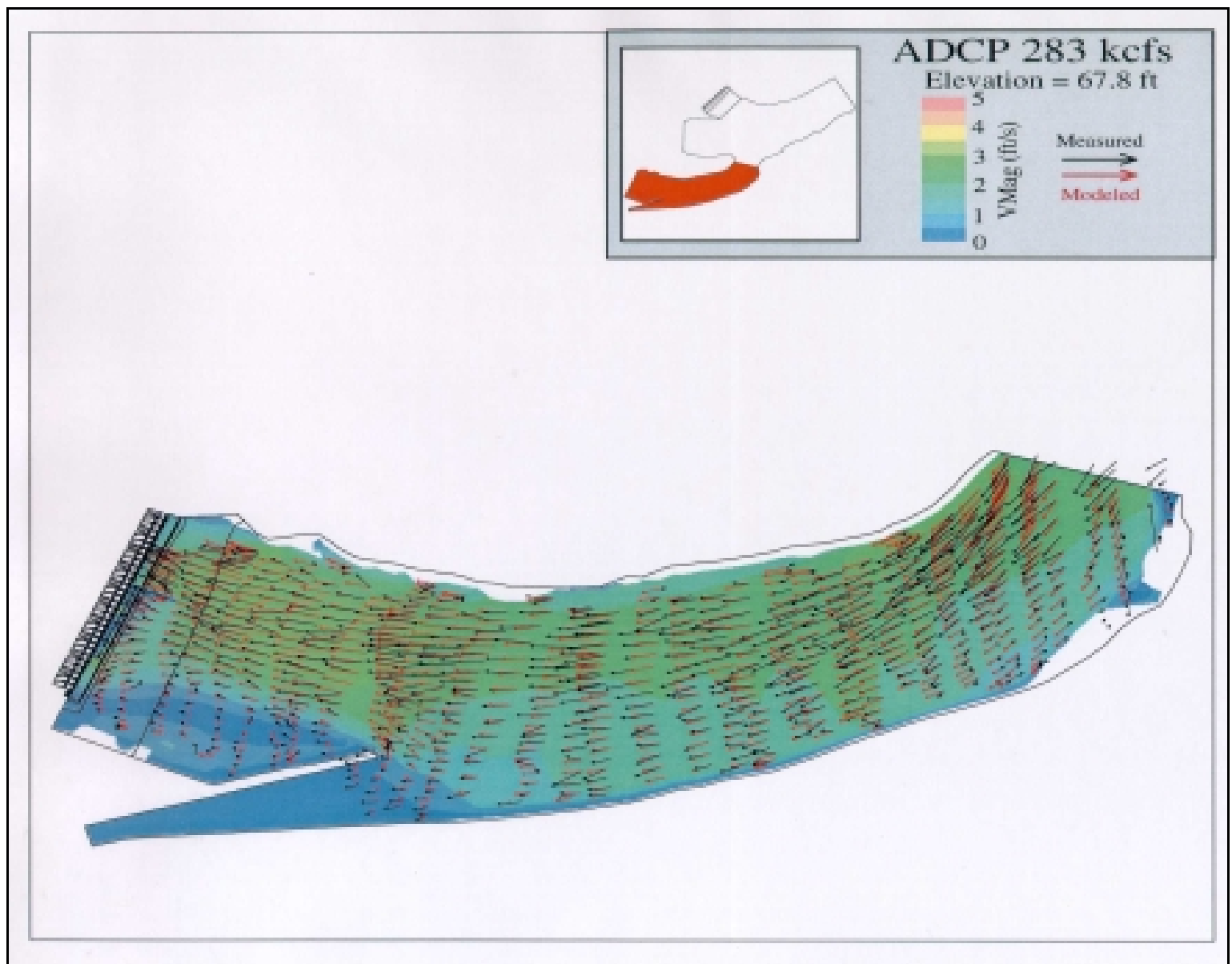

Figure 12. Plan view of B1 forebay showing water velocity (fps) from a CFD model and field measurements with an ADCP (acoustic doppler current profiler). The PSC is not in place. Data are for El. 67.8 ft. Figure provided by L. Ebner (Pers. Comm. December 6, 2000). 


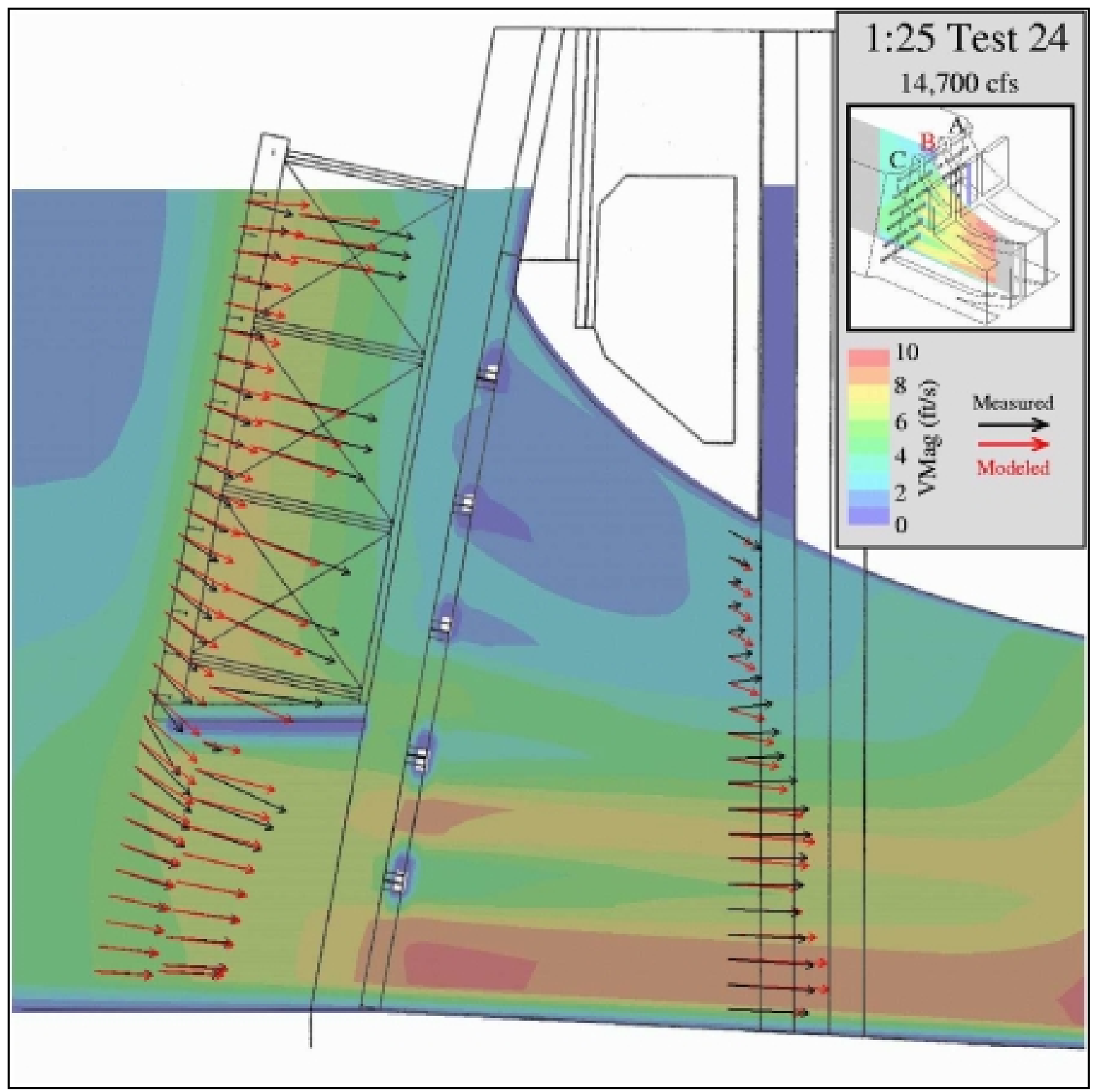

Figure 13. Side view of B1 PSC showing water velocity (fps) from a CFD model and a 1:25 scale physical model. Figure provided by L. Ebner (Pers. Comm. December 6, 2000). 


\subsection{Bonneville Project Passage}

Passage proportions through B1, the spillway, and B2 were estimated using both radio telemetry and fixed hydroacoustics (Table 4). Roughly one-third to one-half of the migrants passing the Bonneville Project in spring and summer 2000 did so at B1. The three-way split in passage roughly corresponded to the proportions of discharge through the main routes at the project.

Table 4. Passage proportions through B1, the spillway, and B2 as estimated using radio telemetry (RT) for steelhead (ST) and chinook (CH1) salmon and fixed hydroacoustics (HA) for the run-at-large in spring and subyearling chinook (CH0) salmon in summer 2000.

\begin{tabular}{ccccccc}
\hline & & & \multicolumn{4}{c}{ Passage Proportion } \\
\hline Population & Season & Technique & B1 & Spillway $^{\mathbf{A}}$ & B2 & Unknown \\
\hline ST & Spring & RT & 0.49 & 0.33 & 0.17 & 0.01 \\
CH1 & Spring & RT & 0.31 & 0.44 & 0.24 & 0.01 \\
Run-at-Large & Spring & HA & 0.35 & 0.44 & 0.21 & 0.00 \\
CH0 & Summer & HA & 0.43 & 0.49 & 0.08 & 0.00 \\
\hline
\end{tabular}

${ }^{A}$ Passage proportion at the spillway is the same as spill efficiency.

\subsection{B1 Forebay Approach and Vertical Distribution}

The downstream migrants that entered the B1 forebay tended to follow the bulk flow as they approached the dam. For example, Faber et al. (2001) tracked acoustic-tagged fish within $100 \mathrm{~m}$ of the dam and found that "... as fish approach the dam they hold to the thalweg..." (p. 19). More tagged fish approached the dam at Units 4-6 than any other region at B1 (Evans et al. 2001, p. 38; Faber et al. 2001, p. 20). As we report in Section 4.4, however, fish generally ceased to follow the bulk flow once they encountered the dam, even sometimes if they presumably had an opportunity to discover a PSC entrance.

Discovery efficiency represents the percentage of tagged fish entering the B1 forebay that actually encounter the PSC. It is estimated by dividing the number of tagged juveniles available to the $\mathrm{PSC}^{4}$ by the total number of tagged fish entering the B1 forebay. ${ }^{5}$ Radio telemetry estimates of discovery efficiency were $74 \%$ for steelhead and $63 \%$ for yearling chinook salmon (Table 5). Acoustic telemetry estimates of discovery efficiency were $79 \%$ for steelhead and $90 \%$ for yearling chinook salmon (Table 5). A relatively large percentage of fish entering the B1 forebay migrated within close proximity $(<6 \mathrm{~m})$ to PSC entrances at Units $1-6$ even though

\footnotetext{
${ }^{4}$ By definition, those within $6 \mathrm{~m}$ of an entrance are "available."

${ }^{5}$ The denominator in these estimates included tagged fish that were detected in the forebay near the dam, but were not detected passing at B1 (radio telemetry -- 33 steelhead and 44 chinook salmon; acoustic telemetry -- 29 steelhead and 3 chinook salmon).
} 
passage was usually possible at the entire powerhouse, Units 1-10. Thus, most smolts seemingly had ample opportunity to discover the PSC flownets.

Table 5. Discovery efficiency estimates based on radio (RT) and acoustic (AT) telemetry at B1 in 2000. Sample sizes of tagged fish are given in parentheses (number detected within $6 \mathrm{~m}$ of a PSC entrance out of the total entering the B1 forebay). Radio telemetry data were obtained from Evans et al. (2001; p. 27). Acoustic telemetry data were obtained from Faber et al. (2001; modified from data on p. 15).

\begin{tabular}{ccc}
\hline & \multicolumn{2}{c}{ Discovery Efficiency } \\
\hline Species & RT & AT \\
\hline ST & $74 \%(356$ of 481$)$ & $79 \%(110$ of 139$)$ \\
CH1 & $63 \%(341$ of 545$)$ & $90 \%(28$ of 31$)$ \\
\hline
\end{tabular}

The vertical distribution of tagged and untagged smolts approaching and encountering the PSC was surface oriented (Evans et al. 2001; Ploskey et al. 2000a). Depth of approach of radiotagged fish to the PSC was determined by the vertical position of the antenna recording the first detection for a particular tagged specimen. Vertical distribution of radio tagged fish was classified as shallow $(<6.5 \mathrm{~m})$ or deep $(>6.5 \mathrm{~m})$. Radio-tagged steelhead were distributed shallower than chinook salmon (steelhead $76 \%$ shallow and $24 \%$ deep; chinook salmon 53\% shallow and 47\% deep; Evans et al. 2001; p. 32). At the face of the PSC (1-3 m away), Ploskey et al. (2000a; p. xvi) detected 92-99\% of the targets above the floor of the PSC (El. $30.5 \mathrm{ft}$ ); in summer, 85-96\% were above the depth of the PSC floor. The vertical distribution of fish approaching the PSC corresponded very well to the vertical position of the PSC entrances.

\subsection{PSC Encounter}

We are interested in what fish do once they encounter the PSC flownets because this behavior will, in part, determine PSC performance. In this section, we characterize PSC encounter using entrance efficiency, movement patterns, and residence time.

\subsubsection{Entrance Efficiency}

The best sources for data on entrance efficiency ${ }^{6}$ were from radio and acoustic telemetry. Hydroacoustic data on entrance efficiency were biased by smolts that were detected at a PSC entrance but then swam back upstream out of the entrance. In short, fish detected with hydroacoustics at PSC entrances had the potential to be counted multiple times. The telemetry analyses, however, dealt only with whether tagged fish detected within $6 \mathrm{~m}$ of an entrance entered or not, no matter how much the fish may have searched or milled.

\footnotetext{
${ }^{6}$ Entrance efficiency is the number entering the PSC divided by the number available within $6 \mathrm{~m}$, for all PSC entrances combined.
} 
Radio telemetry estimates of entrance efficiency were $56 \%$ for steelhead and $63 \%$ for yearling chinook salmon (Table 6). Acoustic telemetry estimates of entrance efficiency were $64 \%$ for steelhead and $79 \%$ for yearling chinook salmon (Table 6). Entrance efficiency was higher for yearling chinook salmon than for steelhead. This difference may be due to either a species- or size-specific response, since steelhead juveniles are larger than chinook salmon juveniles. Many tagged fish that appeared to get close enough to encounter (discover) the PSC flownet seemed to eventually pass through the structure, but others apparently passed elsewhere (under the PSC, Units 7-10, or back out of the B1 forebay).

Table 6. Entrance efficiency estimates based on radio and acoustic telemetry at B1 in 2000. Sample sizes of tagged fish are given in parentheses. Radio telemetry data were obtained from Evans et al. (2001; p. 27, revised June 12, 2001). Acoustic telemetry data were obtained from Faber et al. (2001; modified from data on p. 15).

\begin{tabular}{ccc}
\hline & \multicolumn{2}{c}{ Entrance Efficiency } \\
\hline Species & RT & AT \\
\hline ST & $60 \%(214$ of 356) & $64 \%(70$ of 110$)$ \\
CH1 & $72 \%(246$ of 341$)$ & $79 \%(22$ of 28$)$ \\
\hline
\end{tabular}

\subsubsection{Movement Patterns in the Immediate Vicinity of the PSC}

Three general movement patterns were displayed by radio- and acoustic-tagged fish: direct passage, searching, and milling. Direct passage was characterized by short forebay residence time $(<1 \mathrm{~h})$ before passing into B1. Searching was displayed as active movement back and forth along B1, including the PSC, resulting in longer residence times (1-4 h) than observed for direct passage fish. Milling was defined as relatively long residence times $(>4 \mathrm{~h})$. Of the radio-tagged fish, $31 \%$ of the steelhead (61 of 200) and 47\% of the chinook salmon (100 of 214) passed directly (Table 7), i.e., they passed at the first PSC entrance they encountered (Evans et al. 2001). Results were similar for acoustic-tagged fish (Table 7). Acoustic-tagged steelhead and chinook had a higher percentage of direct passage at night than they did during the day (Table 7). Non-direct movement was also exhibited in the hydroacoustic data (Johnson et al. 2001). 
Table 7. Proportions of acoustic-tagged fish displaying direct passage, searching, and milling movement patterns. Radio telemetry data were obtained from Evans et al. (2001; p. 27). Acoustic telemetry data were obtained from Faber et al. (2001; p. 59).

\begin{tabular}{ccccccccc}
\hline & & \multicolumn{3}{c}{ RT } & \multicolumn{3}{c}{ AT } \\
\hline Species & Entry Time & n & Direct & Non-direct & n & Direct & Searching & Milling \\
\hline ST & Day & --- & --- & --- & 74 & $5 \%$ & $23 \%$ & $72 \%$ \\
& Night & --- & --- & --- & 65 & $54 \%$ & $9 \%$ & $37 \%$ \\
& Combined & 200 & $31 \%$ & $69 \%$ & 139 & $28 \%$ & $17 \%$ & $55 \%$ \\
\hline CH1 & Day & --- & --- & --- & 21 & $19 \%$ & $43 \%$ & $38 \%$ \\
& Night & --- & --- & --- & 10 & $40 \%$ & $20 \%$ & $40 \%$ \\
& Combined & 214 & $47 \%$ & $53 \%$ & 31 & $26 \%$ & $35 \%$ & $39 \%$ \\
\hline
\end{tabular}

Fish tracked with hydroacoustics tended to move upstream and downstream equally, indicating milling behavior (Johnson et al. 2001). Milling behavior was also revealed as fish movements became more variable the closer the fish got to the PSC. Movements of fish tracked with hydroacoustics in the region $18 \mathrm{~m}$ in front of the PSC entrance at Unit 3 were generally obliquely downstream and southerly toward the dam (Johnson et al. 2001). Evans et al. (2001; p. 31) reported "that, in general, both steelhead and chinook salmon moved laterally from north to south along the face of the PSC before passing into it."

Some acoustic-tagged fish and fish tracked with hydroacoustics exhibited positive rheotaxis within $\sim 6 \mathrm{~m}$ of PSC entrances (Faber et al. 2001; Johnson et al. 2001). That is, when some fish got relatively close to the PSC entrances they apparently turned and oriented upstream into the flow. Also, hydroacoustic-tracked fish swam strongly upward in response to the downward component of the PSC flownet at Unit 3 (Johnson et al. 2001, p. 4.16). As determined by acoustic telemetry, fish classified as milling held at the sides of the B1 forebay and were oriented into the flow. Searching fish also showed some orientation into the flow, but direct passage fish had little except for positive rheotaxis at PSC entrances 2B and 3B (Faber et al. 2001, p. 57). Positive rheotaxis indicated that fish responded to environmental stimuli at the PSC, probably related to hydraulic conditions. The process or mechanism for this response and its consequences to PSC passage rates are unknown.

\subsubsection{Forebay Residence Time}

The forebay residence time of tagged fish that passed at B1 was about 4-10 $\mathrm{h}$ (Table 8). Yearling chinook salmon passed the dam a little faster (few hours) than steelhead. Some taggedfish resided for a considerable amount of time in the forebay before passing (e.g., several days), as indicated by the relatively low median values compared to the means (Table 8). 
Table 8. Residence time (hours) for radio- and acoustic-tagged fish that passed at B1. Radio telemetry data were obtained from Evans et al. (2001; p. 19). Acoustic telemetry data were obtained from Faber et al. (2001; p. 17).

\begin{tabular}{ccccccccc}
\hline & \multicolumn{4}{c}{ RT } & \multicolumn{4}{c}{ AT } \\
\hline Species & $\mathbf{n}$ & Mean & Median & Range & n & Mean & Median & Range \\
\hline ST & 335 & 19.7 & 9.7 & $0.1-258$ & 45 & 11.6 & --- & --- \\
CH1 & 382 & 9.8 & 3.4 & $0.1-104$ & 49 & 6.9 & --- & --- \\
\hline
\end{tabular}

\subsection{PSC Collection Efficiency}

Collection efficiency is defined as PSC passage divided by PSC passage plus passage under the PSC. In spring 2000, collection efficiency was estimated on a species-specific basis for yearling migrant steelhead and chinook salmon using radio and acoustic telemetry and for the run-at-large using fixed-location hydroacoustics (Table 9). During the hydroacoustic summer study, subyearling chinook salmon dominated the outmigration. (The study ended before shad became prevalent in the forebay.) Thus, the hydroacoustic results for summer can be ascribed to subyearlings. In this section, we present results for each method separately. In the discussion (Section 5.1), PSC collection efficiency data are collectively tabulated and compared.

Species-specific estimates of collection efficiency are important to decision-makers because different species may respond differently to smolt protection measures. Radio telemetry estimates of collection efficiency were $82 \%$ for steelhead and $76 \%$ for yearling chinook salmon. Acoustic telemetry estimates of collection efficiency were $88 \%$ for steelhead and $96 \%$ for yearling chinook salmon. For the purpose of the decision document, we believe the speciesspecific collection efficiency estimates from radio telemetry should be used, because the relatively large samples sizes for radio telemetry likely yielded more precise estimates than those from acoustic telemetry.

Table 9. Collection efficiency estimates based on hydroacoustics (HA) and radio (RT) and acoustic (AT) telemetry at B1 in 2000. Sample sizes are given in parentheses. Hydroacoustic data were obtained from Ploskey et al. (2000a; p. xviii). Radio telemetry data were obtained from Evans et al. (2001; p. 30, revised June 12, 2001). Acoustic telemetry data were obtained from Faber et al. (2001; p. 15).

\begin{tabular}{ccccc}
\hline & & \multicolumn{3}{c}{ Collection Efficiency } \\
\hline Population & Season & HA & RT & AT \\
\hline ST & Spring & ---- & $82 \%(200$ of 258$)$ & $88 \%(70$ of 80$)$ \\
CH1 & Spring & ---- & $76 \%(214$ of 312$)$ & $96 \%(22$ of 23$)$ \\
Run-at-Large & Spring & $83 \%^{\mathrm{A}}$ & ---- & ---- \\
CH0 & Summer & $84 \%^{\mathrm{A}}$ & ---- & ---- \\
\hline
\end{tabular}

A Adjusted for passage into the sluiceway behind the PSC entrances which was not sampled by hydroacoustics. 
Hydroacoustic estimates of collection efficiency (unadjusted for sluiceway passage behind the PSC) were $72 \%$ for both spring and summer (Figure 14). Note that the hydroacoustic process underestimated collection efficiency because passage into the sluiceway was not sampled. Recall, sluiceway entrances were open in each of the PSC units (B-slots). The radio telemetry data, however, indicated that roughly 50\% (both tagged species combined) of PSC passage was via the sluiceway (S. Evans, pers. comm.). Thus, after adjusting the data for $50 \%$ sluiceway passage in the $\mathrm{PSC}^{7}$ the hydroacoustic estimates of collection efficiency were $83 \%$ for spring and $84 \%$ for summer 2000 (Table 9).

Collection efficiency was also estimated by PSC unit (Figure 14) and by 5-day block (Figure 15) using hydroacoustics. It was highest (>80\%) at Units 5 and 6 (Figure 14), and was always greater than $60 \%$. The lowest collection efficiencies were found at Units 3 and 4 in spring. During the evaluation from April 20 to July 2, 2000, collection efficiency among blocks (5-day) was reasonably consistent (Figure 15).

In conclusion, collection efficiency estimates were:

- Steelhead (based on radio telemetry) - $82 \%$

- Yearling chinook salmon (based on radio telemetry) - 76\%

- Subyearling chinook salmon (based on summer hydroacoustic study with correction for sluiceway passage inside the PSC) $-84 \%$

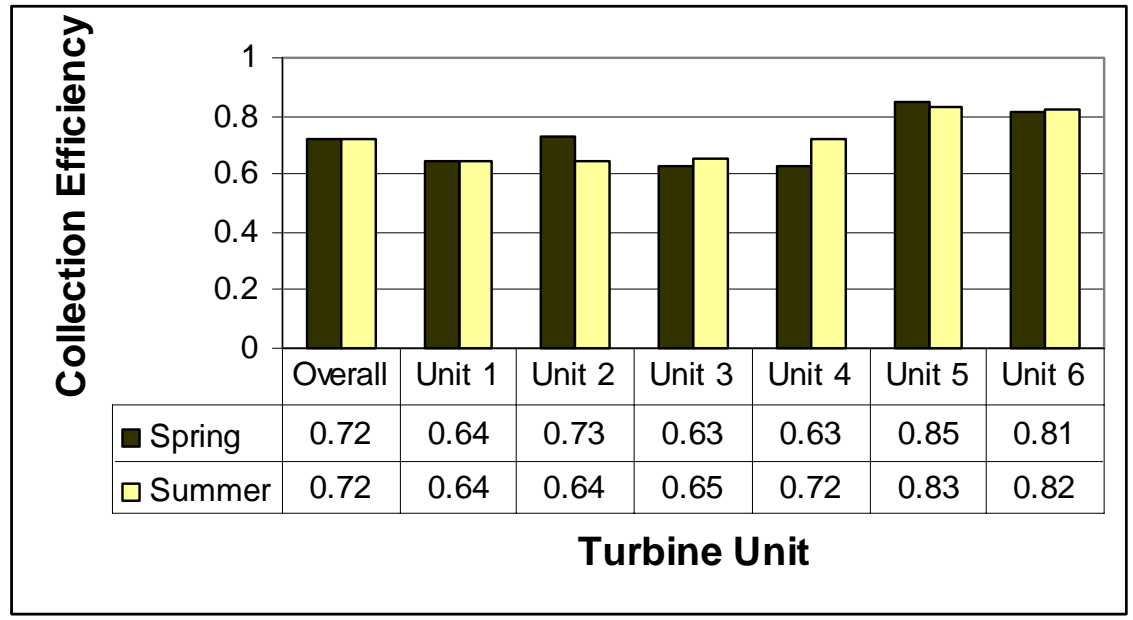

Figure 14. Fixed-location hydroacoustic estimates of collection efficiency by unit and overall for spring and summer separately. Data have not been adjusted for sluiceway passage inside the PSC. Data were obtained from G. Ploskey (Pers. Comm. December 5, 2000).

${ }^{7}$ Collection efficiency from hydroacoustics was adjusted for sluiceway passage as follows:

$C E^{\prime}=\frac{P S C^{*} 2}{P S C * 2+\text { under }}$. 


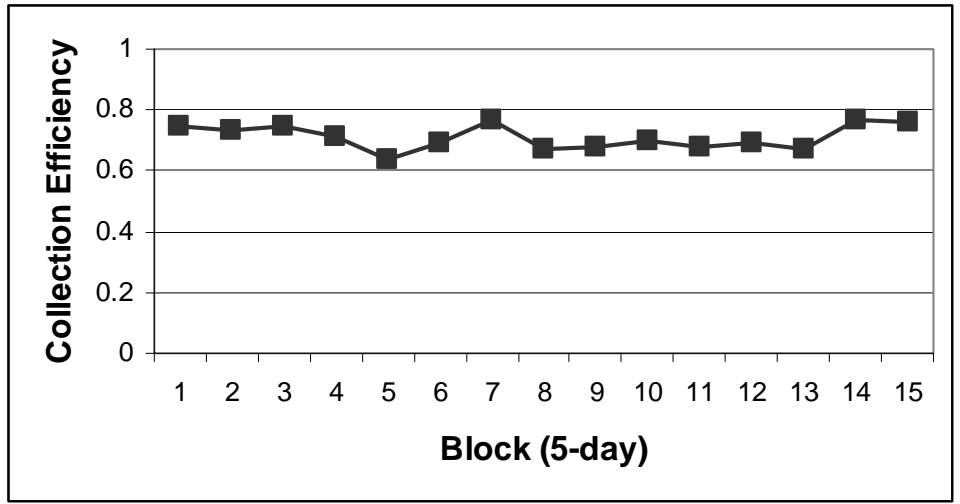

Figure 15. Fixed-location hydroacoustic estimates of collection efficiency by 5-day block beginning on April 20 and ending on July 2, 2000. Data have not been adjusted for sluiceway passage inside the PSC. Data were obtained from G. Ploskey (Pers. Comm. December 5, 2000).

\subsection{PSC Effectiveness}

PSC effectiveness (proportion of fish, i.e., PSC efficiency, divided by proportion of water) was estimated using radio and acoustic telemetry and hydroacoustics. Radio telemetry estimates of effectiveness were 2.49 for steelhead and 2.30 for yearling chinook salmon (Evans et al. 2001; p. 30, revised June 12, 2001). Acoustic telemetry estimates were 2.63 for steelhead and 2.87 for yearling chinook salmon (Faber et al. 2001; p. 15). Based on hydroacoustics, PSC effectiveness was 2.15 in spring and 2.23 in summer (Figure 16). As with collection efficiency, effectiveness was highest at Units 5 and 6 (Figure 16). An effectiveness of 2 means that the percentage of fish moving into the PSC out of total passage was twice the percentage of water passing into the PSC. Trends in effectiveness were similar to those of collection efficiency because the percentage of water passing into each PSC entrance was fairly uniform.

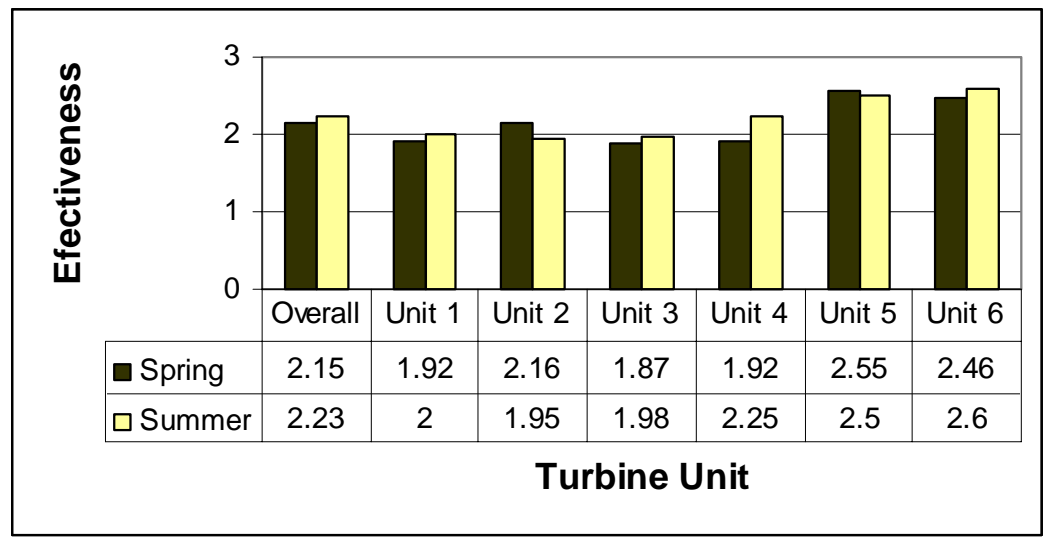

Figure 16. Fixed-location hydroacoustic estimates of PSC effectiveness by unit and overall for spring and summer separately. Data were obtained from G. Ploskey (Pers. Comm. December 5, 2000). 


\subsection{B1 Passage Distribution}

Based on hydroacoustic data, the horizontal distribution of total fish passage at B1 was similar between spring and summer (Figure 17). Passage was highest at Unit 9 and lowest at Unit 10. Horizontal distribution can be affected by dam operations; e.g., recall that Unit 9 passed the most water and Unit 10 the least water in the spring (Figure 10). Fish passage at Units 1-6 comprised about $70 \%$ of total passage at B1 in spring and summer 2000. Out of total passage into the PSC, fish passage at PSC1-2, the extension of the PSC installed in 2000, was $28 \%$ in spring and $23 \%$ in summer.

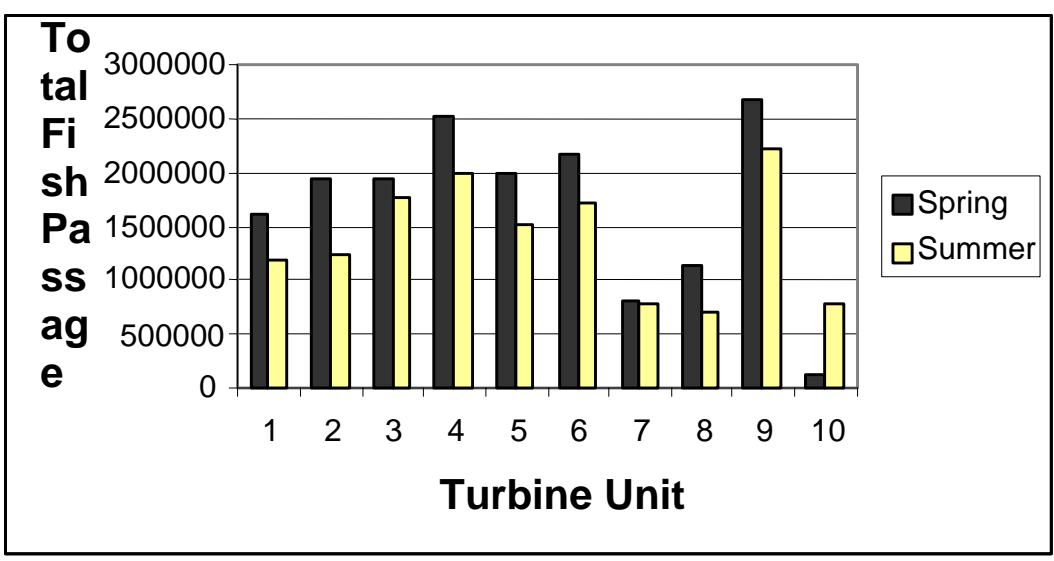

Figure 17. Fixed-location hydroacoustic estimates of total fish passage by unit at B1 for spring and summer separately. Data were obtained from G. Ploskey (Pers. Comm. December 5, 2000). These data are not adjusted by turbine operations.

\subsection{Summary Fish Budgets}

The fish budgets for steelhead and chinook salmon based on radio telemetry are linked to the PSC performance metrics (Figure 18). This figure summarizes B1 passage and PSC performance for radio-tagged fish. We used radio telemetry data for this summary rather than acoustic telemetry because larger sample sizes were available. 


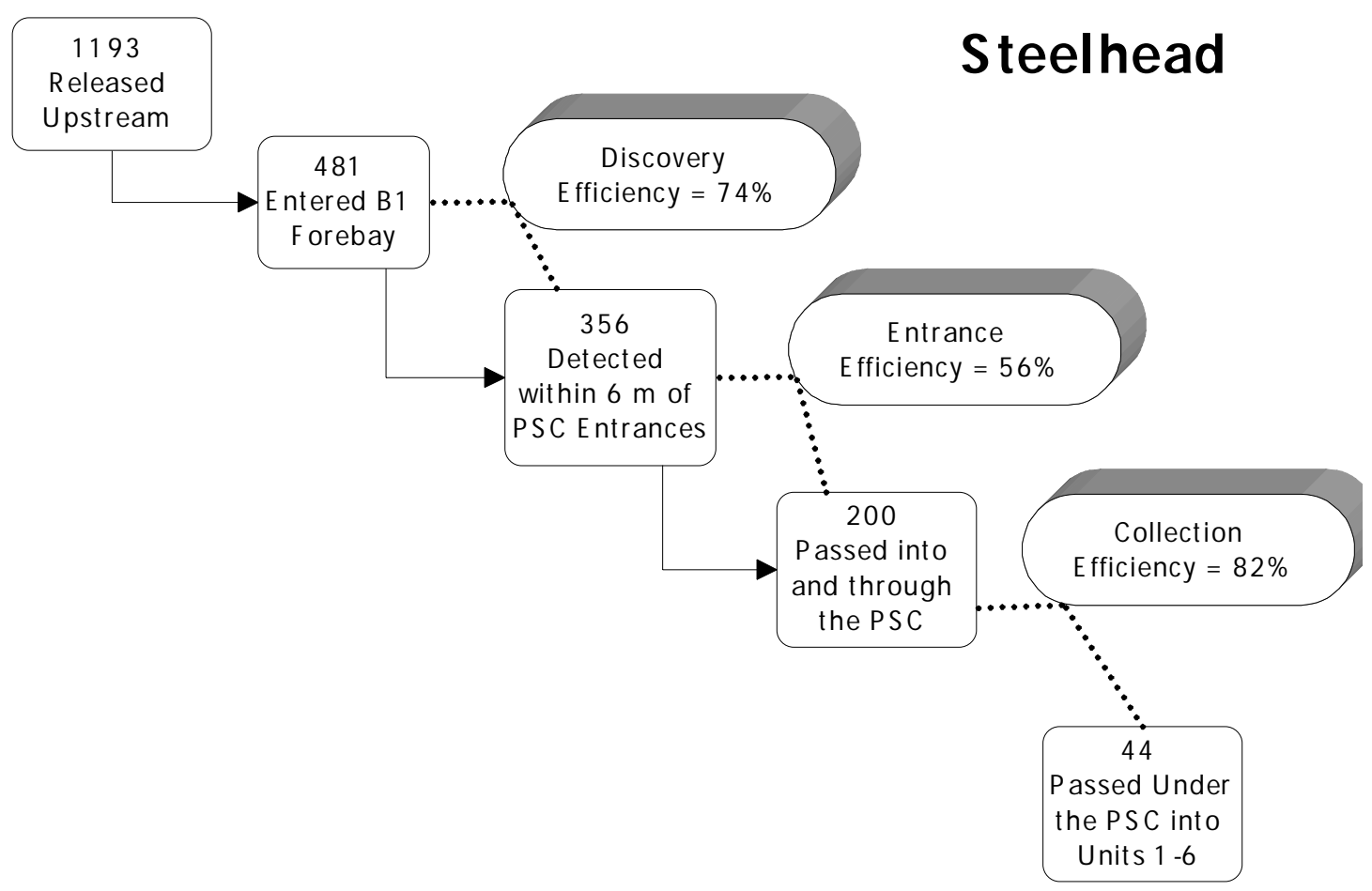

2075

Chinook Salmon

Released

Upstream
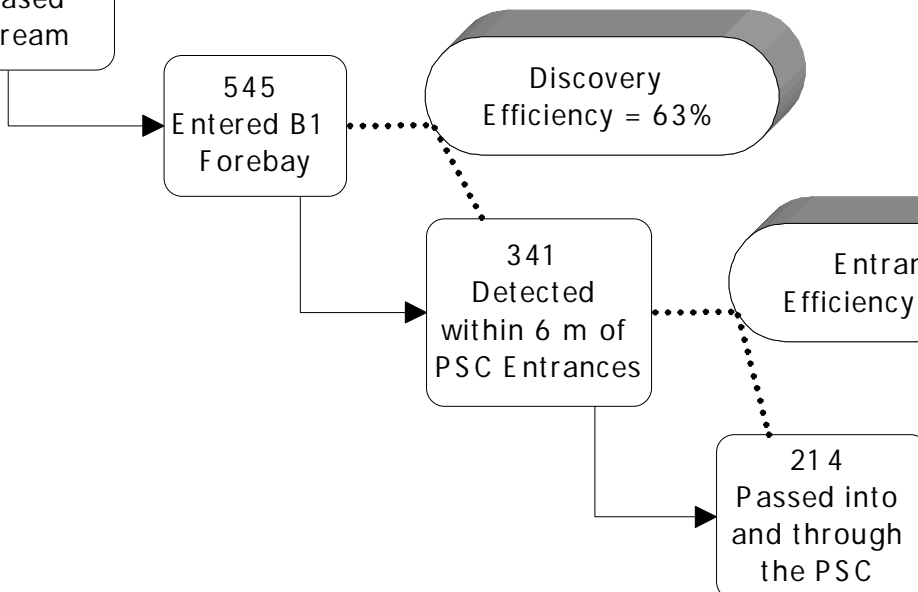

ollection

Efficiency $=76 \%$

the PSC

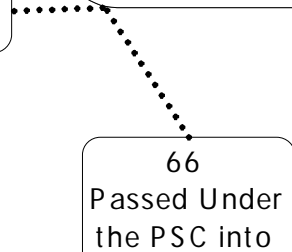

Units 1-6

Figure 18. Fish budget using radio telemetry data for steelhead and chinook salmon separately at B1 in 2000. Data were obtained from Evans et al. (2001, revised June 12, 2001). 


\subsection{Discussion}

The discussion section addresses estimates of PSC collection efficiency, extension of the PSC to Units 1-2, comparison of PSC performance to that of other regional surface bypasses, and uncertainties and the future of deep slot surface bypass at B1.

\subsection{Comparison of Collection Efficiency Estimates}

The three types of data obtained in the 2000 PSC evaluation comport reasonably well with data from prior years (Table 10). Acoustic telemetry estimates, for discovery and entrance efficiencies as well as collection efficiency, were somewhat higher $(\sim 10 \%)$ than those from radio telemetry. The comparison of estimates from multiple techniques demonstrated the value of having more than one independent estimate of collection efficiency.

Comparing PSC performance among years 1998-2000 is difficult because of variability in PSC operations and monitoring and evaluation methods. For example, the PSC had three open entrances in 1998, one in 1999, and six in 2000. Furthermore, sample sizes for radio-tagged fish at B1 were different among years, with 2000 having the highest number (a total of 1,026 radiotagged fish entered the B1 forebay in 2000). Since the 2000 evaluation was the most thorough of the three evaluations, estimates of collection efficiency for 2000 should be used in the decision document (see Section 4.6).

Table 10. Collection efficiency estimates obtained with hydroacoustics (HA), radio telemetry (RT), and acoustic telemetry (AT) at B1 including the two PSC entrance widths (5 ft and $20 \mathrm{ft}$ ).

\begin{tabular}{ccccccc}
\hline & & \multicolumn{2}{c}{ HA } & \multicolumn{2}{c}{ RT $^{\mathbf{A}}$} & AT $^{\mathbf{A}}$ \\
\hline & & 5-ft & 20-ft & 5-ft & 20-ft & n/a \\
\hline $1998^{\text {B }}$ & Spring & $92 \%$ & $88 \%$ & $71 \%$ & $98 \%$ & $\mathrm{n} / \mathrm{a}$ \\
& Summer & $84 \%$ & $92 \%$ & $---{ }^{\mathrm{C}}$ & $---\mathrm{C}^{\mathrm{C}}$ & $\mathrm{n} / \mathrm{a}$ \\
$1399^{\mathrm{B}}$ & Spring & $69 \%$ & $84 \%$ & $53 \%$ & $65 \%$ & $\mathrm{n} / \mathrm{a}$ \\
& Summer & $71 \%$ & $75 \%$ & $\mathrm{n} / \mathrm{a}$ & $\mathrm{n} / \mathrm{a}$ & $\mathrm{n} / \mathrm{a}$ \\
$2000^{\mathrm{D}}{ }^{\mathrm{D}}$ & Spring & $\mathrm{n} / \mathrm{a}$ & $83 \%{ }^{\mathrm{E}}$ & $\mathrm{n} / \mathrm{a}$ & $79 \%$ & $92 \%$ \\
& Summer & $\mathrm{n} / \mathrm{a}$ & $84 \%^{\mathrm{E}}$ & $\mathrm{n} / \mathrm{a}$ & $\mathrm{n} / \mathrm{a}$ & $\mathrm{n} / \mathrm{a}$ \\
\hline
\end{tabular}

A - Obtained by averaging estimates for yearling chinook salmon and steelhead.

в - In 1998 and 1999, collection efficiency was for Units 3-6, CE $=\frac{P S C 3-6}{P S C 3-6+\text { UnderPSC } 3-6}$.

C - Not included because sample size was too small.

D - In 2000, collection efficiency was for Units 1-6, CE $=\frac{P S C 1-6}{P S C 1-6+\text { UnderPSC1-6 }}$

${ }^{\mathrm{E}}$ - Hydroacoustic estimates in 2000 account for sluiceway passage inside the PSC. 


\subsection{PSC Extension to Units 1-2}

The purpose of extending the PSC was to provide an opportunity for smolts to discover a surface passage route at the south side of the powerhouse. This was deemed necessary because of the north to south movement of fish across the forebay of the PSC at Units 3-6 observed in 1998 and 1999. Did the PSC extension from Units 3-6 in 1998-1999 to include Units 1-2 in 2000 perform as intended? Based on hydroacoustics, PSC entrances at Units 1-2 (PSC 1 and 2) passed $28 \%$ of the spring and $23 \%$ of the summer juvenile migrants that used the PSC. PSCs 1 and 2 were as effective as PSCs 3 and 4 (effectiveness $\sim 2$ ), but not as effective as PSCs 5 and 6 (effectiveness $\sim 2.5$ ). Therefore, extending PSC was worthwhile because the surface bypass entrances at Units 1-2 effectively passed a substantial proportion of fish at the PSC (23-28\%) that may have otherwise passed into turbine intakes at Units 1-2.

\subsection{PSC Entrance Configuration and Turbine Intake Occlusion}

The effects of the PSC entrance configuration and turbine intake occlusion are intertwined. The PSC utilized a vertical slot entrance configuration that resembled the one at Wells Dam, but it also occluded the upper two-thirds of the turbine intakes at Units 1-6. It has been hypothesized that turbine intake occlusion will reduce turbine passage rates. Indeed, this seems to have been the case for both the Simulated Wells Intake structure retrofit to the prototype surface bypass at Lower Granite Dam (Anglea et al. 2001) and the prototype Surface Flow Attraction Channel at Wanapum Dam (Kumagai et al. 1997). Recall, however, that the B1 forebay at the face of the dam is much shallower than that at Wells, Wanapum, or Lower Granite dams. Even so, the occlusion at the B1 PSC may have contributed to reduced turbine passage as passage rates under the PSC were relatively low, as shown in a previous study at B1.

In 1996, an experiment with trashrack occlusions at B1 did not reveal negative impacts from the occlusions (Ploskey et al. 1998b). Trashracks at Units 3 and 5 were blocked to El. $33 \mathrm{ft}$ (about $42 \mathrm{ft}$ deep) and sluiceway gates at 3B and 5B were opened. This produced a flow of approximately $750 \mathrm{cfs}$ per gate (assuming forebay El. $75.0 \mathrm{ft}$ ). At Gates $3 \mathrm{~B}$ and 5B, passage into the sluiceway increased and passage into the turbine intakes below decreased, or sluiceway and turbine passage were unchanged (Ploskey et al. 1998b).

Another factor influencing low passage rates under the PSC in 2000 could have been the PSC entrance configuration and its relation to fish vertical distribution. The vertical slots may have simply afforded the downstream migrants an acceptable passage route where they were naturally distributed. Juvenile salmonids were surface-oriented (Ploskey et al. 2000) and certainly reluctant to sound under the PSC as evidenced by the split-and multi-beam data on fish orientation to flow (Johnson et al. 2001). Vertical distribution indicates that theoretically a surface bypass at B1 would need a relatively deep slot to collect the majority of the fish. It is known, however, that fish will move up in the water column to pass into a surface bypass entrance (Johnson et al. 1998). Thus, it is possible a surface bypass entrance that is less deep than the current B1 PSC, but with associated turbine intake occlusion, may perform as well as the deep slot PSC entrances. 


\subsection{Benefits of the PSC}

The PSC would have increased fish passage efficiency (FPE) at Bonneville Dam had it been a functional bypass system. FPE was $56 \%$ for radio-tagged steelhead and $63 \%$ for radiotagged chinook salmon in 2000 (tagged fish that passed at the PSC were not included in these estimates) (Evans et al. 2001; p. 38). Assuming the PSC was a functional bypass, FPE would have increased to $74 \%$ for steelhead and $73 \%$ for chinook salmon, $18 \%$ and $10 \%$ increases, respectively (Evans et al. 2001; p. 38). In addition, this increase in FPE would occur with an effective use of water. The PSC was twice as effective as spill at passing downstream migrants (Table 11).

Table 11. Effectiveness (percent fish divided by percent water) of spill and PSC flow at Bonneville Dam in 2000. Hydroacoustic data are from Ploskey et al. (2000b; p. 56). Radio telemetry data are from Evans et al. (2001; p. 38).

\begin{tabular}{cccccc}
\hline & & \multicolumn{2}{c}{ HA } & \multicolumn{2}{c}{ RT } \\
Species & Season & PSC & Spill & PSC & Spill \\
\hline ST & Spring & --- & --- & 2.5 & 1.0 \\
CH1 & Spring & --- & --- & 2.4 & 1.3 \\
Run-at-large & Spring & 2.2 & 1.4 & --- & --- \\
Run-at-large & Summer & 2.2 & 1.0 & --- & --- \\
\hline
\end{tabular}

\subsection{PSC Performance Compared to Other Regional Surface Bypasses}

Performance of the B1 PSC based on collection efficiency was higher than that for the surface bypass and collector at Lower Granite Dam and compared favorably to that for the Wells Dam surface bypass (Table 12). Thus, the PSC, a deep slot surface bypass, appears to have high potential biologically as a smolt protection measure at B1.

Table 12. Collection efficiencies (CE) for selected surface flow bypasses at Columbia and Snake River dams

\begin{tabular}{|c|c|c|c|c|c|}
\hline Surface Bypass & Year & Season & $\mathbf{C E}$ & Extent & Source \\
\hline \multirow[t]{2}{*}{ B1 PSC } & 2000 & Spring & $87 \%$ & PSC 1-6 & This report \\
\hline & 2000 & Summer & $84 \%$ & PSC 1-6 & \\
\hline \multirow[t]{2}{*}{ Wells Dam } & 1990-1992 & Spring & $89 \%$ & Total project & Skalski et al. (1996) \\
\hline & 1990-1992 & Summer & $89 \%$ & Total project & \\
\hline Lower Granite SBC ${ }^{\mathrm{A}}$ & 2000 & Spring & $62 \%^{\mathrm{B}}$ & Units 4-5 & Anglea et al. (2001) \\
\hline
\end{tabular}

A - SBC stands for surface bypass and collector.

B - SBC configuration with a single entrance and turbines at high load. 


\subsection{Uncertainties and Future Surface Bypass Development at B1}

As promising as the PSC results were, there are some uncertainties with development of a permanent deep slot surface bypass at B1. A permanent system will need to convey surface bypass flow from the forebay to the tailrace. Because the PSC did not do this, the primary concern for future development is the effect on smolt passage from any new hydraulic conditions. Preliminary comparisons of hydraulic conditions for the PSC with those from a prototype permanent system indicated hydraulics might not be that different (Harza et al. 2000). But, this must be investigated further as the hydraulic data are preliminary. Another hydraulic-related uncertainty has to do with smolt response to flow up a ramp in the surface bypass collection area, which will probably be necessary to convey the water and fish. The effect of the presence of trashracks at the surface bypass entrances is another uncertainty. While trashracks are desirable from a debris-protection standpoint, they are generally considered undesirable for fish passage at surface bypasses because of possible adverse entrance hydraulics. A final uncertainty pertains to design and location of the outfall for this high-flow system (15,000 cfs has been proposed). An outfall for a smolt bypass with this amount of flow has not been engineered. But, although there are important uncertainties, in our opinion the uncertainties do not appear at this juncture to be fatal flaws. The capability exists to resolve the uncertainties and develop an efficient and effective stand-alone surface bypass at B1. 


\subsection{Conclusions}

Based on the collective data presented in this report, we conclude:

- Monitoring and evaluation of the prototype surface collector at B1 in 2000 allowed for a thorough evaluation of PSC performance.

- The surface bypass concept as applied at B1 was found to be an efficient way to collect smolts and minimize turbine passage.

- PSC collection efficiency estimates from independent methods (hydroacoustics, radio telemetry, acoustic telemetry) comported reasonably well.

- The best available data for collection efficiency are from the 2000 evaluation. For the purposes of planning and analysis for constant turbine operations, at one slot opening, the following values are recommended:

$$
\begin{array}{ll}
\text { steelhead } & 82 \% \\
\text { yearling chinook salmon } & 76 \% \\
\text { subyearling chinook salmon } & 84 \%
\end{array}
$$

- Collection efficiency was similar between spring and summer, i.e., it did not decrease in summer but stayed largely unchanged while the run composition changed, which is not true of other smolt bypass approaches that have decreasing efficiency as the season progresses.

- Collection efficiency for the B1 PSC was higher than that for the SBC at Lower Granite Dam, and comparable to that for the Wells Dam surface bypass.

- Extending the PSC to Units 1 and 2 in 2000 was worthwhile because the surface bypass entrances at Units 1 and 2 passed a substantial proportion of total PSC fish passage (23-28\%).

- According to radio telemetry data from 2000, the PSC would have increased fish passage efficiency at Bonneville Dam 18\% for steelhead and 10\% for chinook salmon had it been a functional bypass system.

- The PSC was twice as effective (percent fish divided by percent water) as spill at passing fish at Bonneville Dam in 2000.

- There are uncertainties with development of a permanent surface bypass at B1, but it is likely they can be satisfactorily resolved with additional research and development. 


\subsection{Literature Cited}

Anglea, S. and seven co-authors. 2000. Fixed-Location Hydroacoustic Evaluation of the Prototype Surface Bypass and Collector at Lower Granite Dam in 2000. Draft final report submitted to Walla Walla District, U.S. Army Corps of Engineers. November 1, 2000.

Dauble, D., S. Anglea, and G. Johnson. 1999. Surface Flow Bypass Development in the Columbia and Snake Rivers and Implications to Lower Granite Dam. Final report submitted to Walla Walla District, U.S. Army Corps of Engineers. July 21, 1999.

Evans, S. D. and five co-authors. 2001. Passage Behavior of Radio-Tagged Juvenile Salmonids at Bonneville Dam Associated with the Surface Bypass Program, 2000. Draft final report submitted to Portland District, U.S. Army Corps of Engineers. February 27, 2001; revised June 12, 2001.

Faber, D. M., M. A. Weiland, and R. W. Moursund. 2001. Evaluation of Three-Dimensional Fish Behavior Associated with Fish Passage through, Around, or Under Prototype Surface Flow Bypass Structures. Preliminary report submitted to Portland District, U.S. Army Corps of Engineers. January 13, 2001.

Harza Engineering Company, HDR, Mobrand Biometrics, R2 Resource Consultants, BioAnalysts, and ENSR. 2000. Bonneville First Powerhouse Deep Slot Surface Bypass Prototype Alternatives Study. Phase 3 report submitted to the Portland District, U.S. Army Corps of Engineers. December 4, 2000.

Harza Northwest, Inc. and ENSR Consulting and Engineering. 1996. Bonneville First Powerhouse 1997 Prototype Surface Collector System. Letter Report submitted to the Portland District, U.S. Army Corps of Engineers. August 30, 1996.

Hensleigh, J.E. and six co-authors. 1998. Movement, Distribution, and Behavior of RadioTagged Yearling Chinook Salmon and Juvenile Steelhead in the Forebay of Bonneville Dam, 1998. Preliminary report submitted to Portland District, U.S. Army Corps of Engineers. September 11, 1998.

Johnson, G.E. and A.E. Giorgi. 1999. Development of Surface Flow Bypasses at Bonneville Dam: A Synthesis of Data from 1995 to 1998 and a M\&E plan for 2000. Final report submitted to Portland District, U.S. Army Corps of Engineers. October 8, 1999.

Johnson, G.E. and nine co-authors. 1998. Fixed-Location Hydroacoustic Evaluation of the Prototype Surface Bypass and Collector, Spill Efficiency, and Fish Guidance Efficiency at Lower Granite Dam in Spring and Summer 1997. Final report submitted to Walla Walla District, U.S. Army Corps of Engineers. January 1998. Battelle No. PNWD-2417.

Johnson, G.E., A.E. Giorgi, and M.W. Erho. 1997. Critical Assessment of Surface Flow Bypass Development in the Lower Columbia and Snake Rivers. Completion report submitted to Walla Walla District, U.S. Army Corps of Engineers. April 30, 1997. 
Johnson, R.L. and six co-authors. 2001. Hydroacoustic Evaluation of Fish Behavior at Bonneville Dam First Powerhouse: 2000 Prototype Surface Flow Bypass. Final report submitted to Portland District, U.S. Army Corps of Engineers. February 2001.

Kumagai, K.K., B.H. Ransom, H.A. Sloan, and H. Charve,. 1997. Effectiveness of a Prototype Surface Flow Attraction Channel for Passing Juvenile Salmon and Steelhead Trout at Wanapum Dam During Spring 1997. Final report submitted to Grant County PUD. December 23, 1997.

Ploskey, G. R. and eight co-authors. 2000a. Hydroacoustic Evaluation of a Prototype Surface Collector and In-Turbine Screens At Bonneville Dam First Powerhouse in 2000. Draft technical report submitted to Portland District, U.S. Army Corps of Engineers. December 2000.

Ploskey, G. R. and eight co-authors. 2000b. Hydroacoustic Evaluation of Fish Passage through Bonneville Dam in 2000. Draft technical report submitted to Portland District, U.S. Army Corps of Engineers. December 2000.

Ploskey, G., M. Hanks, G. Johnson, B. Nagy, and C. Schilt. 1999. Hydroacoustic Evaluation of Downstream Migrant Fish Passage at The Dalles Dam in 1999. Draft final report submitted to Portland District, U.S. Army Corps of Engineers. December 1999.

Ploskey, G.R., W.T. Nagy, L.R. Lawrence, D.S. Patterson, C.R. Schilt, P.N. Johnson, and J.R. Skalski. 1998a. Hydroacoustic Evaluation of Juvenile Salmonid Passage through Experimental Routes at Bonneville Dam in 1998. Draft report submitted to Portland District, U.S. Army Corps of Engineers. December 1998.

Ploskey, G. R.; L.R. Lawrence, P.N. Johnson, W.T. Nagy, and M.G. Burczynski. 1998 b. Hydroacoustic Evaluations of Juvenile Salmonid Passage at Bonneville Dam including Surface-Collection Simulations. Final report submitted to Portland District, U.S. Army Corps of Engineers. April 1998. WES No. EL-98-4.

Rakowski, C. L., J. A. Serkowski, M. C. Richmond, and K. P. Recknagle. 2000. Development and Application of a 3D CFD Model for the Bonneville Project Powerhouse 1 and Powerhouse 2. Draft letter report submitted to Portland District, U.S. Army Corps of Engineers. July 17, 2000.

Skalski, J.R., G.E. Johnson, C.M. Sullivan, E. Kudera, and M.W. Erho. 1996. "Statistical Evaluation of Turbine Bypass Efficiency at Wells Dam on the Columbia River, Washington." Canadian Journal of Fisheries and Aquatic Sciences. 1996; 53(10):21882198.

USACE. 1995. Lower Snake and Columbia Rivers Surface Bypass and Collection Systems Prototype Development Program. Report prepared by Portland and Walla Walla Districts, U.S. Army Corps of Engineers. August 1995. 


\section{Appendix A. \\ Comments from National Marine Fisheries Service on Draft Report and Responses}

Draft comments were received from the National Marine Fisheries Service regarding the Phase 1 report dated December 8, 2000 (Johnson and Carlson 2000). Those comments are reproduced below with our responses embedded.

To: Willis

Fr: $\quad$ Ruff

Subject: Monitoring and Evaluation of the Prototype Surface Collector at Bonneville First Powerhouse in 2000: Synthesis of Information on PSC Performance Phase 1 Report (Draft)

Dear Mr. Willis:

We appreciate the opportunity to review the subject report. We have the following comments:

1. General - We agree that this synthesis report is an important step in pulling together numerous and diverse 2000 Prototype Surface Collector (PSC) evaluations. We have also discussed with your staff the idea of convening an ad hoc Fish Facilities Design and Review Work Group (FFDRWG) meeting to fully discuss all research results from 2000 PSC performance evaluations, with a goal of using the best possible performance inputs for Simpas modeling associated with the current Bonneville Decision Process.

Response was not necessary.

2. General - We understand that some additional updated preliminary research reports for year 2000 have either recently been distributed, or will be in the near future. We expect that this synthesis report will be revised to reflect this new information, and that the revised outputs will be factored into Bonneville Decision Process numerical modeling.

We used the most recent research reports available for this final report.

3. Page 3, Section 2.1 - Mean entrance velocities and discharge quantities contrast to those in the B-1 Deep-slot Surface Collector Prototype Alternatives Study, Phase 3 Submittal, dated December, 2000. We recommend these quantities be reconciled.

The PSC data on p. 3 were revised using the best available entrance flow and velocity data (obtained from K. Kuhn, CENWP-HY, 505-808-4897).

4. Page 5, Section 2.2, Sluiceway Operations - We believe the comments herein suggesting that operation of the sluiceway reversed upstream flow at the sides and immediately downstream of the slot entrances are misleading. While this was no doubt true at the surface, sluiceway 
flow had little on hydraulic conditions from just below the surface and at greater depths within the PSC.

We agree. The text was clarified accordingly.

5. Page 7, Section 3.1 - Entrance efficiency (EE) is described as the ratio of total PSC passage to total number of fish within $6 \mathrm{~m}$ of the PSC entrances. This metric is an indicator of volitional movement of tagged fish into the entrance. For example, if many tagged fish pass within $6 \mathrm{~m}$ of all six deep-slot entrances, EE would be a lower ratio. This would suggest that a better entrance configuration may be worth investigating. In contrast, page 14, Section 4.2.2 describes the EE in a manner that appears inconsistent with the former definition, and compares A...tagged fish ...within $6 \mathrm{~m}$ of an entrance and its ultimate fate (through the PSC or not). While this wording is confusing, it seems to suggest the ratio of tagged fish entering the PSC to the fate of all tagged fish (either entering the PSC, passing under the PSC, or passing somewhere else). This ratio appears to be similar to the Collection Efficiency (CE), referenced on page 15, Section 4.2.3, except for inclusion of the number of fish passing somewhere else in the denominator. Therefore, this report does not appear to reference a metric that addresses the issue of volitional movement of fish into the PSC deep-slot entrance. We recommend this data from 2000 research be compiled to provide an EE more compatible with the Section 3.1 definition, showing the ratio of PSC fish entry versus total number of detections within the $6 \mathrm{~m}$ distance from the entrance.

The definition of the entrance efficiency metric in the methods section was the basis for the entrance efficiency estimates reported in the results section. We clarified the text describing entrance efficiency results for radio-tagged fish.

6. Page 12 , Section 4.1 .3 - Generally characterizing forebay water velocity as $3 \mathrm{fps}$ is misleading. While it may be this high nearer the surface and immediately upstream of the PSC, average velocity further upstream (and considering the entire channel width) is lower. Without color coding and a larger scale, Figures 12 and 13 were hard to use as a reference. We would appreciate receiving a copy of this report with colored figures.

We agree. Reference to $3 \mathrm{fps}$ was removed from the text. The final report will be in color.

7. Page 14, Section 4.2.2 - The EE metric is especially important in the context of whether the deep-slot entrance is a vital part of the 2000 PSC, or whether (for instance) the upper intake occlusion was the vital PSC component that retarded turbine entrainment. We know that few fish passed under the PSC during both 1998-2000. It may be that a series of surface overflow entrances passing flow directly into the lateral bypass channel, with the same occlusion feature, could have passed as many (or more) fish. This issue is especially important in the context of the surface collection alternative now being considered in the Bonneville Decision Process. The assumption that the deep-slot entrance is the vital PSC feature adds another \$55 million to the cost of this option, and another five years to design, build, and prototype-test for the optimum transition ramp between the deep-slot entrance and the lateral bypass channel (see B-1 Deep-slot Surface Collector Prototype Alternatives Study, Phase 3 
Submittal). Neither this report, nor the alternatives study, reference the idea that the composite upper intake occlusion, which successfully and substantially reduced turbine entrainment at Wanapum and Lower Granite (and will be prototype-tested at The Dalles in 2001) may be just as effective with the surface entrance as the deep-slot entrance design. We would expect this type of discussion to be considered somewhere within the synthesis report, presumably in the Discussion section.

This topic was explored in a new subsection in the Discussion section.

8. Page 15, Section 4.2.3 - While we understand that the $72 \%$ hydroacoustic CE does not account for fish passing into the sluiceway, it is unclear how an adjustment for $50 \%$ sluiceway passage of radio-tagged fish jumps to an increase of hydroacoustic CE from $72 \%$ to $83-84 \%$ for the PSC during spring and summer. Clarification is needed here.

A footnote showing the equation used to adjust the hydroacoustic estimate for sluiceway passage, as determined by radio telemetry, was added to the report.

9. Page 19, Table 6 - CE appears to be the defining metric for PSC performance in this report. However, there is a risk in adopting one metric too quickly. For example, the 20' slot sustained a radio-telemetry CE of $97.5 \%$ in 1998 . Based on the $2000 \mathrm{CE}$ of $83 \%$, it appears from this table that performance was nearly $15 \%$ lower in 2000. A description of why this is or is not so is warranted.

The radio telemetry data were fairly variable between years (1998-2000). Presumably this was because of different sample sizes and dam operations between years. These points were made in the text.

10. Page 20, Table 7 B CE at Lower Granite in 2000 equates to R4-5 for the surface bypass collector at single entrance and high turbine loading. Our interpretation suggests this metric value (as listed in Figure 17 of the referenced report) should be 35\%, rather than the $65 \%$ figure in this report.

The corresponding value for collection efficiency of the surface bypass at Lower Granite Dam is $R_{4-5}$. Anglea et al. (2001, p. 5.2) reported this to be $62 \%$ for the best configuration/operation tested at Lower Granite from 1996 to 2000.

We appreciate the opportunity to comment on this document. Please contact Steve Rainey, (503) 230-5418, or Gary Fredricks, (503) 231-6855, if there are questions or comments.

Sincerely, Jim Ruff 